\title{
Grain-scale deformation mechanisms and evolution of porosity in experimentally deformed Boom Clay
}

\author{
Bernhard Schuck ${ }^{1,2}$, Guillaume Desbois ${ }^{1}$, Janos L. Urai ${ }^{1}$ \\ 1) Structural Geology, Tectonics and Geomechanics, RWTH Aachen University, Lochnerstrasse \\ 4-20, 52056 Aachen, Germany \\ 2) GFZ Potsdam, Sektion 4.2: Geomechanik und Wissenschaftliches Bohren, Telegrafenberg, \\ 14473 Potsdam, Germany
}

\begin{abstract}
Boom Clay is a soft, slightly overconsolidated, uncemented claystone considered as potential host material for a radioactive waste repository in Belgium. We studied the evolution of microfabrics in samples which were shortened to $20 \%$ bulk strain in consolidated-undrained (CU) triaxial experiments at effective confining pressures of $0.375,0.750$ and $1.5 \mathrm{MPa}$, respectively.
\end{abstract}

Results show a geomechanical behavior in agreement with previous studies, with total strain partly localized in shear zones and partly diffuse outside the shear zones. The diffuse strain is accommodated by pore compaction without any discernible microstructural changes compared to the starting material. In the shear zones, pore collapse reduces SEM-visible porosity and further deformation mechanisms within the shear zones are particulate flow (grain boundary sliding), particle rotation and the formation of microcracks. There is no evidence for comminution of quartz and feldspar grains. Strain localization on macro- and mesoscale is governed by viscosity contrasts between harder clasts (e.g. quartz and feldspar) embedded in a soft, porous, phyllosilicate-rich matrix.

Our microstructures are comparable to those observed in Boom Clay deformed naturally and in the Excavation Damaged Zone of the Underground Research Facility. This suggests that our results are representative of Boom Clay's geomechanical behavior at the microscale.

\section{Introduction}

Geomechanically, Boom Clay is a phyllosilicate-rich geomaterial transitional between soils and rocks (Petley, 1999; Dehanschutter et al., 2004). The platy habit of clay minerals fosters deformation of phyllosilicate composites by particulate flow, where slip is accommodated along the crystal's basal planes (e.g. Morgenstern and Tchalenko, 1967; Borradaile et al., 1981; Porter et al., 2000), resulting in low coefficients of friction of clay-rich materials (Wojatschke et al., 2016). In addition to particulate flow, there are further mechanisms commonly attributed to the deformation of clay-rich materials: (i) cataclasis involving displacement and / or rotation of particles as well as particle fragmentation with associated particle size reduction; (ii) diffusive mass transfer comprising material removal, transportation and deposition; (iii) intracrystalline plasticity resulting in permanent lattice distortion manifested by crystal kinking and bending (Blenkinsop, 2000; Fossen, 2016). The occurrence and intensity of individual deformation 
mechanisms depends on a broad variety of controlling factors such as size (Logan et al., 1987; Klinkenberg et al., 2009), shape (Lupini et al., 1981; Klinkenberg et al., 2009) and spatial distribution of particles (Klinkenberg et al., 2009) as well as the presence of a preferred particle orientation (e.g. foliation; Morgenstern and Tchalenko, 1967; Rutter et al., 1986; Laurich et al., 2014; Ikari et al., 2015). Equally important is the fraction of frictionally strong (e.g. quartz) to weak (e.g. phyllosilicates) phases and their spatial relationship (i.e. presence or absence of interconnected weak layers; Kenney, 1977; Rutter et al., 1986; Logan et al., 1987; Niemeijer and Spiers, 2007; Collettini et al., 2009; Haines et al., 2009; Jessel et al., 2009; Schleicher et al., 2010; Haines et al., 2013; den Hartog and Spiers, 2014). Further factors influencing failure mechanisms are orientation of stress with respect to foliation (Morgenstern and Tchalenko, 1967; Dehandschutter et al., 2005b; Niemeijer and Spiers, 2007), water content (Moore and Lockner, 2007; Morrow et al., 2017), degree of cementation (Desbois et al., 2017a), temperature of deformation (den Hartog and Spiers, 2014), chemical state of mineral constituents (Kenney, 1977) and syndeformational changes of material properties (Laurich et al., 2017).

Imaging grain-scale deformation microstructures (at sub-micrometre scale) in clay-rich geomaterials is challenging because such materials are difficult to prepare with conventional methods without intensive damage to microfabrics. Microstructural studies are nevertheless required to fully understand the bulk rheology of these materials (Morgenstern and Tchalenko, 1967; Logan et al., 1979, Lupini et al., 1981; Rutter et al., 1986; Logan et al., 1992; Saffer and Marone, 2003; Dehandschutter et al., 2004, Dehandschutter et al., 2005a; Dehandschutter et al., 2005b; Colletini et al., 2009; Haines et al., 2009; Haines et al., 2013; Kaufhold et al., 2016; Desbois et al., 2017a). Ion beam methods (FIB: Focussed Ion Beam; BIB: Broad Ion Beam) enable the preparation of high-quality cross sections and, in combination with scanning-electron microscopy (SEM), currently pave the way to new fields of qualitative and quantitative investigations of phyllosilicate-rich geomaterials (Desbois et al., 2009; Milliken \& Reed, 2010; Heath, 2011; Klaver et al., 2012; Hemes et al., 2013; Houben et al., 2013; Desbois et al., 2014; Houben et al., 2014; Laurich et al., 2014; Warr et al., 2014; Hemes et al., 2015; Klaver et al. 2015; Hemes et al., 2016; Laurich et al., 2017; Laurich et al., 2018). This approach allows investigating deformed phyllosilicate-rich geomaterials at nanometre-resolution with unprecedented clarity (Laurich et al., 2014; Desbois et al., 2017a; Laurich et al., 2017).

The Boom Clay Formation constitutes of a plastic, uncemented, detrital claystone (Horseman et al., 1987; Boisson et al., 2005; Vandenberghe et al., 2014). Its deposition in the Early Oligocene (33.9 - 28.1 Ma BP) at the southwestern margin of the North Sea basin is related to one opening episode of this rift system (Bergerat and Vandycke, 1994; Vandenberghe et al., 2014). After burial, up to $100 \mathrm{~m}$ uplift related to the Alpine orogeny caused a slight overconsolidation (Horseman et al., 1987; Vandycke, 1992; Mertens et al., 2003; Dehandschutter et al., 2004; Boisson et al., 2005; Vandenberghe et al., 2014). Boom Clay crops out in northern Belgium and dips slightly towards NE, where its maximum thickness is about $150 \mathrm{~m}$ with the top of the formation reaching a depth of more than $300 \mathrm{~m}$ (Figure S1; Vandenberghe et al., 2014). Periodic silt-clay sorting processes of mainly quartz and clay phases resulted in a charactersistic layering of the formation expressed in alternating, several meters to centimetre thick silt-rich ("clayeysilt") and silt-poor ("silty-clay") bands (Honty and de Craen 2012, Vandenberghe et al. 2014). Associated with this layering, inversely correlated quartz and clay contents show large variations (Table 1; Honty and de Craen 2012, Vandenberghe et al. 2014; Zeelmaekers et al., 2015). BIB-SEM microstructural analyses of undisturbed Boom Clay reveal a fine-grained matrix 
formed by clay minerals wrapping around more rigid and larger phases. Clay minerals display a shape preferred orientation (SPO) parallel to bedding (Desbois et al., 2009; Hemes et al., 2013; Desbois et al., 2014).

Understanding deformation of Boom Clay is of special interest because of its application to geotechnical problems such as foundations (Schittekat et al., 1983; Mendoza, 2004) and its potential as host rock for the disposal of nuclear waste in deep geological formations (Horseman et al. 1987; Taylor and Coop 1993; ONDRAF-NIRAS, 2001; Bernier et al., 2007). To this end, various studies aimed for a geomechanical characterisation of the Boom Clay (Boisson et al., 2005). Critical state mechanics (see Roscoe et al., 1958; Roscoe and Burland; 1968; Schofield and Wroth, 1968; Wood, 1990) allows describing the rheological response of Boom Clay to deformation and its brittle-ductile transitional behaviour (e.g. Horseman et al., 1987; Horseman et al., 1993; del Olmo et al., 1996; Dehandschutter et al., 2004; Dehandschutter et al., 2005a; Dehandschutter et al., 2005b; Sultan et al., 2010; Deng et al., 2011a). Research comprises investigations of material stiffness and yield behaviour (e.g. Mendoza, 2004; Piriyakul, 2006; Sultan et al., 2010; Labiouse et al., 2013; Bésuelle et al., 2014), the coupling between rheology and temperature variations (e.g. Horseman et al., 1987; Horseman et al., 1993; Baldi et al., 1991a; Baldi et al., 1991b; del Olmo et al., 1996; Cui et al., 2009; Monfared et al., 2012). Furthermore, petrophysical properties such as permeability (e.g. Coll, 2005; Deng et al., 2011b, Bésuelle et al., 2014), and the influence of pore-pressure variations on the geomechanical behaviour (Horseman et al., 1987; Horseman et al., 1993; Barnichon and Volckaert, 2003; Monfrared et al., 2012; Yu et al., 2012; Bésuelle et al., 2014) have been studied.

Table 1: Bulk mineralogical composition of Boom Clay (Laenen, 1997; Honty and de Craen, 2012; Vandenberghe et al., 2014; Zeelmaekers et al., 2015) and mineralogical composition of sample EZE 62 from the 0N-Mol-1 borehole, considered as reference for samples investigated in this study.

\begin{tabular}{lccccc}
\hline Non-clay minerals & \multicolumn{2}{c}{ Amount [wt\%] } & \multicolumn{2}{c}{ Clay minerals } & \multicolumn{2}{c}{ Amount [wt\%] } \\
& bulk & EZE 62 & & bulk & EZE 62 \\
\hline Quartz & $20-60$ & 23 & $2: 1$ phases & $7-24$ & 17 \\
K-Feldspar & $10-15$ & 6 & Smectite & $7-23$ & 13 \\
Plagioclase & $10-15$ & 2 & Illite-Smectite & $5-18$ & 15 \\
Calcite & $<4$ & $<1$ & Illite & & 16 \\
Dolomite & \pm & $<1$ & & & 3 \\
Siderite & \pm & $<1$ & Kaolinite & $10-15$ & \\
Pyrite & $<3$ & 3 & Chlorite & & \\
Gypsum & $<1$ & $<1$ & & \\
Anatase & $<1$ & $<1$ & & \\
Apatite & $<2$ & & & \\
Glauconite & $<1$ & & & \\
Rutile & $<1$ & 2 & & \\
Zircon & $<5$ & & & & \\
Organic Matter & $<1$ & & & \\
\hline
\end{tabular}

Natural deformation of Boom Clay has been studied in outcrops (Dehandschutter et al., 2005a; Dehandschutter et al., 2005b) and at $223 \mathrm{~m}$ depth in the Underground Research Facility (URF) at Mol-Dessel, Belgium (Dehandschutter et al., 2002; Dehandschutter et al., 2004; Dehandschutter et al., 2005a). In both settings (Dehandschutter et al., 2005a), Boom Clay exhibits a brittle-ductile transitional behaviour manifested by the occurrence of compacted, 
ductile (non-dilatant) shear bands with slickensides, hybrid shear fractures and dilatant fractures (Dehandschutter et al., 2004; Dehandschutter et al., 2005b). Small faults of predominantly (oblique) dip-slip and subordinately reverse kinematics range in size from $\mathrm{m}$ to $\mu \mathrm{m}$ (Dehandschutter et al., 2002; Dehandschutter et al., 2004; Dehandschutter et al., 2005a). Matrix porosities are remarkably reduced at and in close vicinity to these discontinuities (Dehandschutter et al., 2005a). Faulting-related microstructures are Riedel-shears and enéchelon tension gashes in dilatant fractures and displacement-parallel shape-preferred orientations (SPO) originating from grain-boundary sliding and rotation of clay particles in (hybrid) shear faults (Dehandschutter et al., 2004; Dehandschutter et al., 2005a; Dehandschutter et al., 2005b).

Based on microstructural observations and using critical state mechanics, discontinuities are interpreted to have formed consecutively during compaction and consolidation related to burial and the subsequent uplift of the formation: ductile shear bands are interpreted to have formed first before or close after the onset of uplift, followed by hybrid fractures generated during uplift before tensile fractures formed close to the surface (Dehandschutter et al., 2005b). However, this interpretation does not describe how deformation localized. Moreover, (i) observations were mostly made at shear zone edges because they are easy to recognize macroscopically (Laurich et al., 2014) but leave the internal structure of the shear zone elusive, (ii) splitting samples along shear planes induces surface damages, and (iii) the remaining high topography of broken samples does not allow quantitative stereology analyses.

Deformation experiments, both consolidated-drained (CD) and consolidated-undrained (CU), on Boom Clay samples show (i) variations in main rheological and petrophysical properties (Table 2) which are a function of mineralogy, burial depth and bedding-related fabric anisotropy, and (ii) a slight strain-softening behaviour as expected for slightly overconsolidated clays (Horsemann et al. 1993; Coll, 2005; Piriyakul, 2006; Sultan et al., 2010; Bésuelle et al., 2014). Boom Clay's slight overconsolidation with a preconsolidation stress in the order of 5 to 6 $\mathrm{MPa}$ could explain the common absence of strain localization in deformation experiments at confining pressures above $5 \mathrm{MPa}$ (Baldi et all., 1991a; Baldi et al., 1991b; Horsemann et al., 1993; Coll, 2005). At these conditions, samples are barreled with macroscopically diffuse strain (Coll, 2005). At confining pressures below $5 \mathrm{MPa}$ strain localization during deviatoric loading was observed to develop along shear zones oblique to $\sigma_{1}$ (Horsemann et al. 1993; Coll, 2005; Sultan et al., 2010; Monfrared, 2012; Yu et al., 2012; Bésuelle et al., 2014). Angles between shear plane and $\sigma_{1}$ increase from $30-35^{\circ}$ to $40-44^{\circ}$ with confining pressure (Coll, 2005). Furthermore, pore pressure drops measured in $\mathrm{CU}$ experiment and volumetric strain analyses in $\mathrm{CD}$ experiments indicate both that Boom Clay tends to dilate by the formation of micro-cracks, which tend to be suppressed with increasing confining pressures (Horsemann et al. 1993; Coll, 2005; Sultan et al., 2010; Monfrared, 2012; Yu et al., 2012; Bésuelle et al., 2014). Permeability during the triaxial tests reported above does not seem to change significantly even when strain is localized (Coll, 2005; Bésuelle et al., 2014; Monfrared et al., 2012).

Microstructures developed during experimental deformation of Boom Clay are welldeveloped slickensides (Horsemann et al., 1993) and bent clay aggregates (Al-Mukthar et al., 1996), in shear zones which display strong SPOs parallel to displacement and have a denser fabric arguing for compaction, rotation and sliding mechanisms (Horsemann et al., 1987; Vasseur et al., 1995, Al-Mukthar et al., 1996; Djéran-Maigre et al, 1998; Yu et al., 2012). 
Horsemann et al. (1993) attribute the residual strength in stress-strain curves after failure to the reorientation of clay aggregates within the shear zone. The co-occurrence of slickensides (Horsemann et al., 1987; Taylor and Coop, 1993) and minor dilatant micro-fractures (Horsemann et al., 1987; Sultan et al., 2010; Yu et al., 2012) indicates that Boom Clay is close to the dilatancy transition (Ingram and Urai, 1999) at confining pressures $<5 \mathrm{MPa}$.

Table 2: Review of Boom Clay material properties compiled after Schittekat et al., (1983), Horseman et al., (1987), Al-Mukthar et al. (1996), del Olmo et al. (1996), Mertens et al., 2003; Boisson et al., 2005; Coll, 2005; Dehandschutter et al. (2005a), Bésuelle et al., 2013, Hemes et al. (2016) and references therein.

\begin{tabular}{|c|c|}
\hline Bulk density (saturated) $\left[\mathrm{kg} \mathrm{m}^{-3}\right]$ & $1900-2100$ \\
\hline Water content [wt\%] & $19-30$ \\
\hline Porosity (physical) [\%] & $35-49 \%$ \\
\hline Porosity (connected) [\%] & $23-40 \%$ \\
\hline Permeability $\left[\mathrm{m}^{2}\right]$ & $2 \times 10^{-19}-4 \times 10^{-19}$ \\
\hline Hydraulic conductivity $\left[\mathrm{m} \mathrm{s}^{-1}\right]$ & $5 \times 10^{-9}-5 \times 10^{-12}$ \\
\hline Young's modulus [MPa] & $200-400$ \\
\hline Unconfined compressive strength [MPa] & 2 \\
\hline Poisson's ratio & $0.40-0.45$ \\
\hline Shear modulus [MPa] & 37 \\
\hline Angle of internal friction $\left[^{\circ}\right]$ & $11-22$ \\
\hline Apparent cohesion [MPa] & $0.08-0.3$ \\
\hline Overconsolidation ratio $\left(\mathrm{p}_{\max }^{\prime} / \mathrm{p}_{\text {actual }}^{\prime}\right)^{\mathrm{a}}$ & $\sim 1-1.5$ \\
\hline
\end{tabular}

Microstructural analyses using BIB-SEM have not been applied to study experimentally deformed Boom Clay yet. Therefore, this study aims to give a first detailed look at microstructures before and after experimental deformation of Boom Clay in CU tests imaged by BIB-SEM. This will substantially contribute to understand deformation mechanisms and strain localization of this material.

Furthermore, this contribution aims to compare the microstructures presented here with the ones observed in Boom Clay deformed naturally and artificially during excavation of the URF at Mol-Dessel (Dehandschutter et al., 2002; Dehandschutter et al., 2004; Mertens et al., 2004; Dehandschutter et al., 2005a; Dehandschutter et al. 2005b).

Finally, results of this investigation on Boom Clay, an uncemented clay, are compared with results obtained by studying the geomechanical behaviour of Callovo-Oxfordian Clay, a diagenically cemented mudrock, using a similar methodological approach (Desbois et al., 2017a). This approach allows assessing variations in rheology of clay-rich geomaterials with differing degrees of diagenetic cementation.

\section{Material and methods}

\subsection{Material}

The Boom Clay core material used in this study originates from the ON-Mol-1 borehole drilled in spring 1997 (Figure S1, ONDRAF/NIRAS, 2001). The sample (ON/MOL/1/269.27- 
269.47) was preserved in vacuum-packed Al-coated-poly-ethylene barrier foil immediately after coring, stored at $7{ }^{\circ} \mathrm{C}$ and opened for this study. It is very similar to and originates about $20 \mathrm{~cm}$ below the sample from the Terhagen Member of the Boom Clay referenced as EZE 62 in Zeelmakers et al. (2015), which consequently is considered as reference (Table 2).

\subsection{Consolidated-undrained triaxial deformation}

Cylindrical samples (diameter: $40 \mathrm{~mm}$; height: $80 \mathrm{~mm}$ ) were cut dry with long axis perpendicular to bedding with a low-speed saw. Three undrained deformation experiments at effective confining pressures $\left(\sigma_{c}^{\prime}\right)$ of $0.375,0.750$ and $1.500 \mathrm{MPa}$ (Figure 1a), were performed at the Institute of Foundation Engineering, Soil Mechanics, Rock Mechanics and Waterways Construction (RWTH Aachen University, Germany) following the norm DIN 18137-2-CU. Before the test, samples were jacketed in rubber tube with stripes of filter paper, re-saturated with following laboratory-internal standard approaches - deionized water and then consolidated. Subsequently, the sample was deformed normal to bedding at a constant displacement rate of $4.2 \times 10^{-5} \mathrm{~mm} \mathrm{~s}^{-1}$ to an axial bulk strain of $20 \%$. Axial stress was derived by calculating the ratio between the load force and the transverse area of sample $\left(A=V_{0} \times\left(h_{0}-\Delta h\right)^{-1}=A_{0}(1-\varepsilon)^{-1}\right.$; where $V_{0}$ and $A_{0}$ are respectively the initial volume and the transverse area of sample, $h_{0}$ the initial length of the sample, $\Delta \mathrm{h}$ the shortening and $\varepsilon$ the bulk strain).

After the deformation experiments, samples were unloaded and dried slowly over several months (without the rubber jackets) to minimize drying cracks, in an atmosphere with stepwise decreasing humidity. Relative humidity (RH) was controlled by different salt solutions (KCL $\mathrm{RH}: 85 \%$; $\mathrm{NaCl}-\mathrm{RH}: 76 \%$; air $-45 \%<\mathrm{RH}<60 \%$ ), at room temperature (Hemes et al., 2016).

Bulk porosities $(\Phi)$ before and after the experiments were determined as follows:

$$
\Phi=1-\left(\rho_{\mathrm{d}} / \rho_{\mathrm{g}}\right)
$$

with $\rho_{\mathrm{d}}$ being the dry density and $\rho_{\mathrm{g}}$ being the grain density (determined with a pycnometer). The dry density is defined as

$$
\rho_{d}=\rho_{w} /(1+w)
$$

where $\rho_{\mathrm{w}}$ indicates the wet density and $\mathrm{w}$ the water content. While grain density is an intrinsic material property which is not affected by the experiments, dry density changes in response to deformation. 

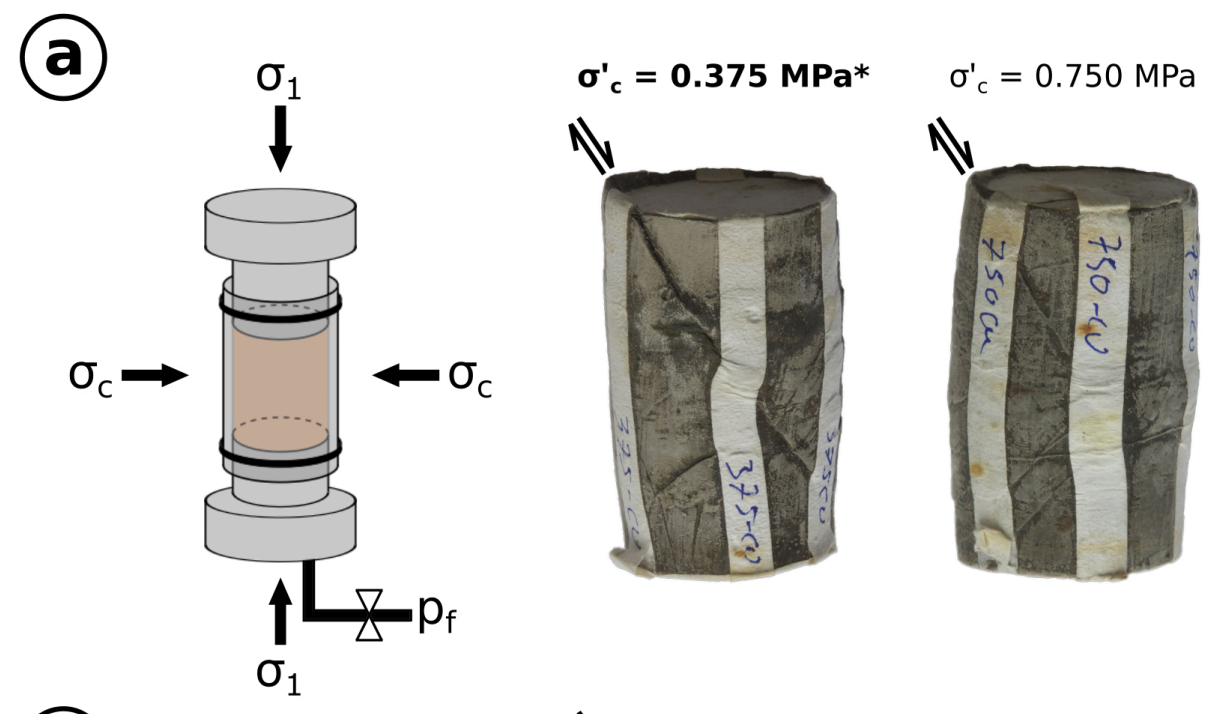

$$
\sigma^{\prime}{ }_{c}=1.500 \mathrm{MPa} *
$$
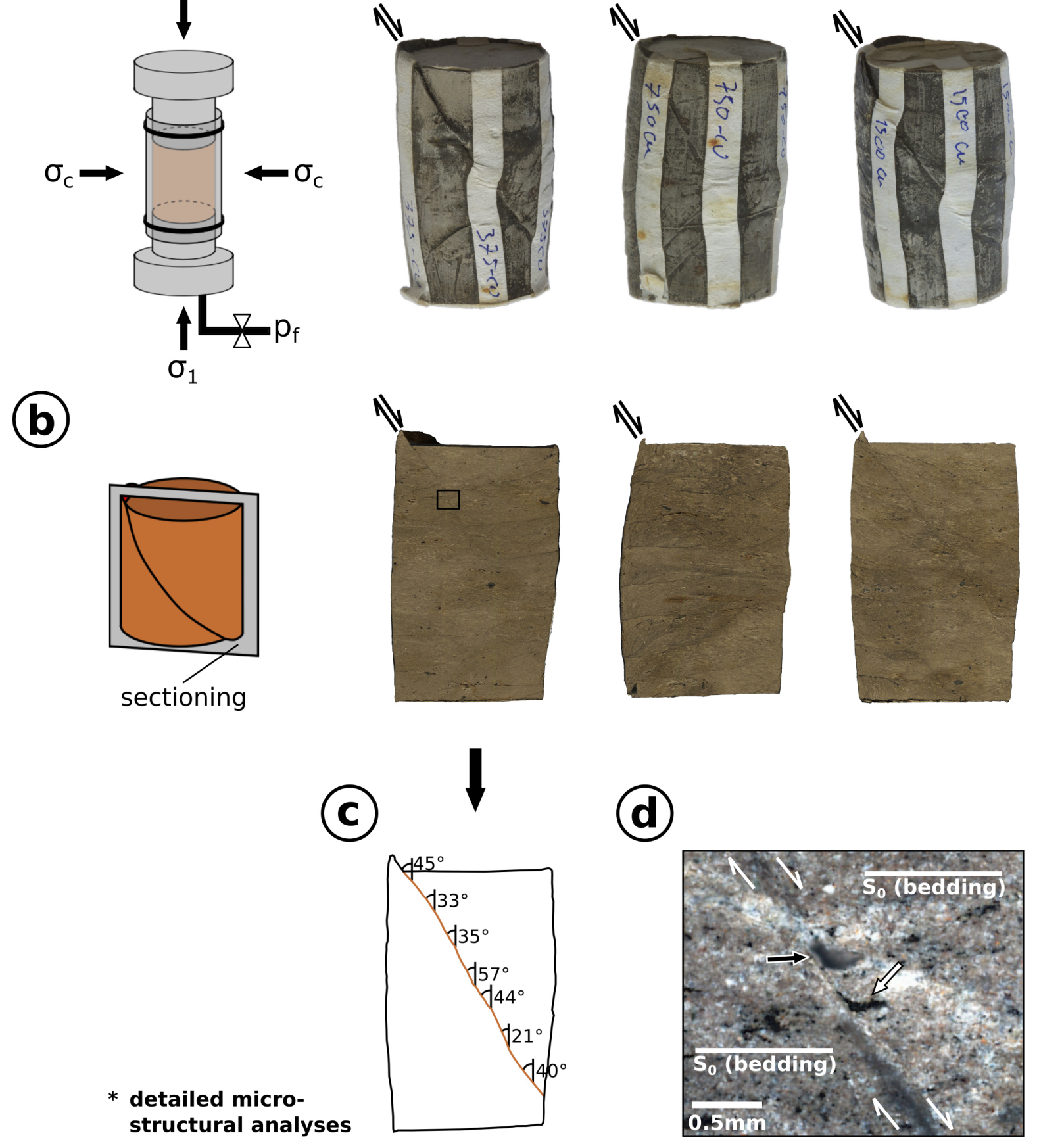

Figure 1: (a) Sketch (left) of setup of the three confined-undrained deformation experiments and deformed samples with visible shear planes. Axial compression $\left(\sigma_{1}\right)$ is oriented normal to bedding. Initial sample dimensions were $4 \mathrm{~cm}$ (diameter of cylinder) by $8 \mathrm{~cm}$ (height of cylinder). Confining pressure $\left(\sigma_{\mathrm{c}}=\right.$ $\sigma_{2}=\sigma_{3}$ ) increases from $0.375 \mathrm{MPa}$ over $0.750 \mathrm{MPa}$ to $1.5 \mathrm{MPa}$. Detailed microstructural analyses have been performed on samples confined at $0.375 \mathrm{MPa}$ and $1.5 \mathrm{MPa}$. (b) Sketch of sample-sectioning (left) and sectioned samples. Black box in left sample gives location of (d). A displacement gradient from top left (larger displacement) to bottom right (smaller displacement) is visible in all samples. This displacement gradient is exemplified at the sample confined at $0.750 \mathrm{MPa}$, where dark-brown, horizontal bedding planes are more offset towards the sample top compared to the sample bottom. (c) Sketch of deformed sample confined at $0.375 \mathrm{MPa}$ with trace of shear plane highlighted in orange. While the average angle between $\sigma_{1}$ and the shear plane is about $32^{\circ}$ it varies locally between $21^{\circ}$ and $57^{\circ}$. (d) Detail (reflected light microscopy) of deformed sample confined at $0.375 \mathrm{MPa}$. White half-arrows indicate location and width of the shear zones and its sense of displacement. Along the shear zone there are deflected markers such as pores (black arrow) and minerals (white arrow). 


\subsection{BIB-SEM imaging of deformed microstructures and image processing}

After deformation and drying, samples deformed at $0.375 \mathrm{MPa}$ and $1.5 \mathrm{MPa}$ were cut dry parallel to both $\sigma_{1}$ and the dip direction of the visible shear plane with a low speed diamond saw (Figure 1b). As the shear zone was macroscopically barely visible on the cut surfaces (Figures $1 \mathrm{~b}$ \& c), a micro-relief-replica (Lamipeel; Kraus, 2002) was prepared to facilitate its identification. Subsequently, Eight sub-samples $\left(7 \times 7 \times 5 \mathrm{~mm}^{3}\right)$ containing the shear zone were prepared by using a low-speed micro diamond saw without fluids and pre-polished mechanically with SiC grinding papers (down to 2400 grade) before performing BIB-polishing (slope cutting, JEOL SM09010, 6kV, 8hrs) or flat polishing (Leica Tic3X, 7.5kV, $7 \mathrm{hrs}$ ) as described in Desbois et al. (2009), Klaver et al. (2012), Hemes et al. (2013), Houben et al. (2013), Desbois et al. (2014), Houben et al. (2014), Laurich et al. (2014), Hemes et al. (2015), Hemes et al. (2016), Laurich et al. (2017) and Laurich et al. (2018). All BIB-polished surfaces contain the normal to the shear plane (Figures 1b \& d). Furthermore, an undeformed sample was also BIB-polished with the bedding normal to the polished surface to act as reference for the starting material. In addition, two samples were broken along and two across the shear zones similar to the technique described in Dehandschutter et al. (2004), Dehandschutter et al. (2005a) and Dehandschutter et al. (2005b).

Samples for SEM (Zeiss Supra 55) were coated with $7 \mathrm{~nm}$ tungsten (Leica EM ACE600) to allow imaging fine microstructural details in true 2D flat cross-sections including sub-micron pores in the clay matrix. Secondary electron (SE) images were acquired to image pores $(3 \mathrm{kV}$ acceleration voltage; $8 \mathrm{~mm}$ working distance (WD); 20,000x magnification; $14.7 \mathrm{~nm}$ pixel size), backscattered electron (BSE) images to visualize phase density contrasts (20 kV acceleration voltage; $8 \mathrm{~mm}$ WD; 5,000x magnification; $58.6 \mathrm{~nm}$ pixel size), and energy dispersive X-ray (EDX) analyses to map the elemental composition $(20 \mathrm{kV}$ acceleration voltage; $8 \mathrm{~mm}$ WD; 3,500x magnification; $83.8 \mathrm{~nm}$ pixel size).

Single images were stitched automatically using Kolor Autopano giga 2.0 software (Houben et al., 2014) to produce megapixel mosaics of SE2 and BSE images. Segmentation of pores was done automatically by using a combination of image filters and thresholdings in Fiji (Schindelin et al., 2012) followed by manual cleaning with special attention to intragranular pores (Hemes et al., 2013). Quartz and feldspar grains of the undeformed sample and three subsamples of the sample deformed at a confining pressure of $0.375 \mathrm{MPa}$ were segmented manually based on EDX element maps overlain on BSE mosaics in ArcGIS. Image analyses was performed with ArcGIS. Data were used for quantitative evaluation of microstructures (e.g. size, shape, orientation of the bounding ellipses' long axis) of the undeformed sample and the three subsamples of the sample deformed at a confining pressure of $0.375 \mathrm{MPa}$ (grains and pores) as well as of the deformed sample confined at $1.5 \mathrm{MPa}$ (pores). Grain size data were used to perform power-law analyses to investigate if grain size distributions are fractal. The methodological details of this analysis are given in Hemes et al. (2013).

The representativeness of SEM-visible porosity measurements (Kanit et al. 2003) was analysed for the sample deformed at $0.375 \mathrm{MPa}$ confining pressure by referring to the local porosity theory which uses covariance analysis. This approach provides a statistical tool to calculate the relative error of the property estimations as a function of the size of the analysed area and the number of realizations of that area (i.e. the relative error on the porosity 
measurement from an ideal representative infinite area). Details and applications are given in Hemes et al. (2014), Keller et al. (2015) and Philipp et al. (2017).

\section{Results}

\subsection{Macroscopic deformation}

Samples show a trajectory of strain hardening, a poorly defined peak stress and subsequent onset of minor strain softening (Figure 2a). Strain at peak stress decreases with increasing confining pressure $16.73 \%\left(\sigma_{c}^{\prime}: 0.375 \mathrm{MPa}\right), 14.58 \%\left(\sigma_{c}^{\prime}: 0.750 \mathrm{MPa}\right)$ and $13.34 \%\left(\sigma_{c}^{\prime}: 1.5\right.$ $\mathrm{MPa}$ ) (Figure 2a; Table 3). Conversely, maximum shear stress increases with increasing confining pressure $343 \mathrm{MPa}\left(\sigma_{c}^{\prime}: 0.375 \mathrm{MPa}\right), 508 \mathrm{MPa}\left(\sigma_{c}^{\prime}: 0.750 \mathrm{MPa}\right)$ and $859 \mathrm{MPa}\left(\sigma_{c}^{\prime}: 1.5\right.$ $\mathrm{MPa}$ ) (Figure 2a; Table 3). After the onset of deformation, pore pressures increase as strains increase (Figure 2b). Samples confined at $0.350 \mathrm{MPa}$ and $0.750 \mathrm{MPa}$ show decreasing pore pressures above $6 \%$ strain. Pore pressure of the sample confined at $0.350 \mathrm{MPa}$ slightly increases between $\sim 12.2$ and $16.1 \%$ strain before decreasing again. Pore pressure in the sample confined at 1.5 MPa increases steadily with increasing strain, plateaus between $~ 11$ and $15.7 \%$ and decreases afterwards. Bulk porosities are smaller after deformation (Table 3 ). Porosity reduction is less pronounced for samples deformed at lower confining pressure $(\sim 7 \%$ for the sample deformed at $0.375 \mathrm{MPa}$ confining pressure vs. $\sim 11 \%$ for the sample confined at 1.5 $\mathrm{MPa})$.

Table 3: Sample properties before (US: undeformed sample) and after (DS: deformed sample) deformation as well as strain and stress at failure, respectively.

\begin{tabular}{|c|c|c|c|c|c|c|}
\hline \multirow{2}{*}{ Sample } & \multicolumn{2}{|c|}{$\sigma_{c}^{\prime}=0.375 \mathrm{MPa}$} & \multicolumn{2}{|c|}{$\sigma_{c}^{\prime}=0.750 \mathrm{MPa}$} & \multicolumn{2}{|c|}{$\sigma_{c}^{\prime}=1.5 \mathrm{MPa}$} \\
\hline & US & DS & US & DS & US & DS \\
\hline Sample height [cm] & 7.99 & 6.31 & 7.92 & 6.24 & 7.94 & 6.26 \\
\hline Sample diameter [cm] & 3.80 & 4.20 & 3.80 & 4.20 & 3.79 & 4.16 \\
\hline Sample density $\left[\mathrm{kg} \mathrm{m}^{-3}\right]$ & 2.06 & 2.09 & 2.08 & 2.12 & 2.12 & 2.17 \\
\hline Porosity [\%] & 34.0 & 31.7 & 32.9 & 30.3 & 32.2 & 28.6 \\
\hline Strain at failure [\%] & \multicolumn{2}{|c|}{16.73} & \multicolumn{2}{|c|}{14.58} & \multicolumn{2}{|c|}{13.34} \\
\hline$\sigma_{1}^{\prime}$ at failure $[\mathrm{MPa}]$ & \multicolumn{2}{|c|}{1.058} & \multicolumn{2}{|c|}{1.761} & \multicolumn{2}{|c|}{3.189} \\
\hline$\sigma_{3}^{\prime}$ at failure $[\mathrm{MPa}]$ & \multirow{2}{*}{\multicolumn{2}{|c|}{$\begin{array}{l}0.373 \\
0.343\end{array}$}} & \multicolumn{2}{|c|}{0.744} & \multicolumn{2}{|c|}{1.471} \\
\hline Maximum shear stress [MPa] & & & \multicolumn{2}{|c|}{0.508} & \multicolumn{2}{|c|}{0.859} \\
\hline
\end{tabular}

Evaluating these results in a Mohr diagram (Figure 2c) gives an apparent cohesion of 0.117 $\mathrm{MPa}$ and an angle of internal friction of $18.7^{\circ}$.

Deformed samples are slightly barrelled and display shear zones indicating localized deformation (Figures $1 \mathrm{a} \& \mathrm{~b}$ ). Angles between $\sigma_{1}$ and shear planes are about $32^{\circ}$ in case of the samples confined at $0.375 \mathrm{MPa}$ and $0.750 \mathrm{MPa}$, respectively, and with roughly $36^{\circ}$ slightly larger in case of the sample confined at $1.5 \mathrm{MPa}$ (Figures $1 \mathrm{~b} \& \mathrm{c}$ ). Maximum shear displacement at offset sample tops (Figure $1 \mathrm{~b}$ ) is about $4 \mathrm{~mm}$ for samples deformed at confining pressure of $0.375 \mathrm{MPa}$ and $1.500 \mathrm{MPa}$, respectively. The sample deformed at $0.750 \mathrm{MPa}$ confining pressure is offset by up to $2 \mathrm{~mm}$. All samples exhibit a displacement gradient, i.e. offsets measured at suitable markers such as bedding foliations, decrease along the shear plane (Figures 1b \& c). Furthermore, occasional markers are deflected along the shear plane (Figure 1d). Samples were 
deformed to $20 \%$ axial strain, or $16.8 \mathrm{~mm}$ axial shortening (Table 3). As the displacement along the shear zone (at an angle to $\sigma_{1}$ between and $32^{\circ}$ and $36^{\circ}$, respectively) is up to $4 \mathrm{~mm}$, the maximum contribution of movement along the shear zone to total shortening ranges between $19.3 \%\left(\sigma_{c}=1.5 \mathrm{MPa}\right)$ and $20.2 \%\left(\sigma_{\mathrm{c}}=0.375 \mathrm{MPa}\right)$. This implies that most strain is non-localized.

(a)

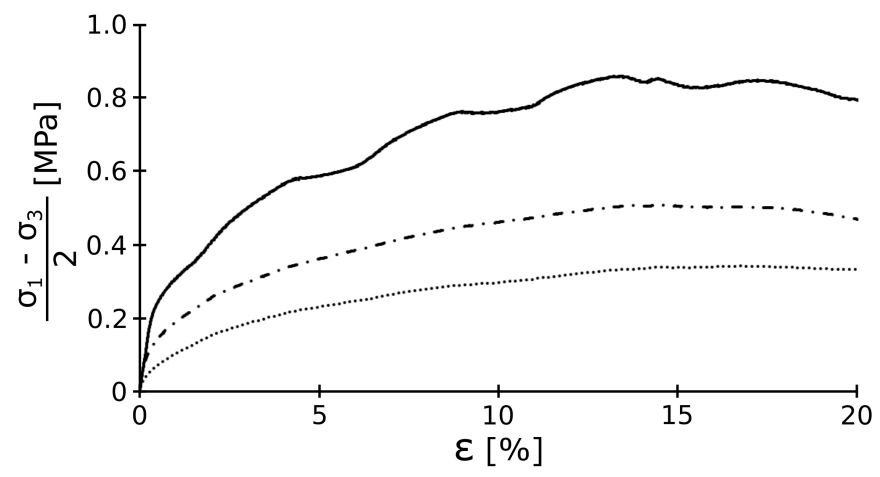

(b)

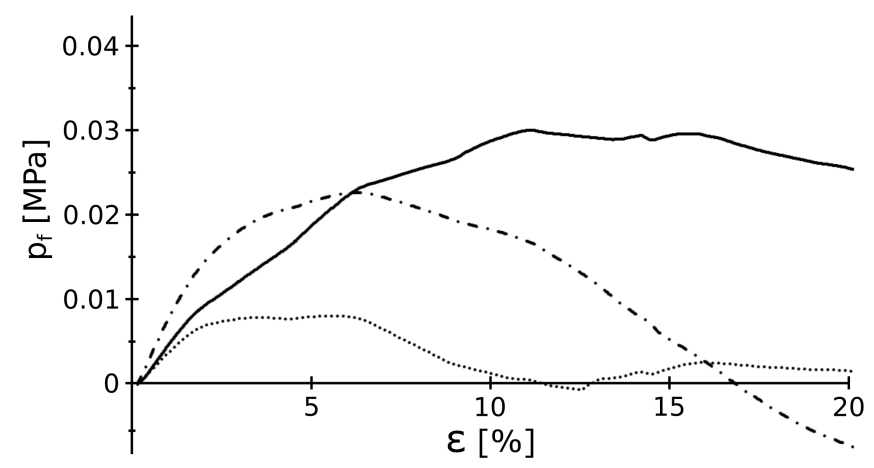

(c)

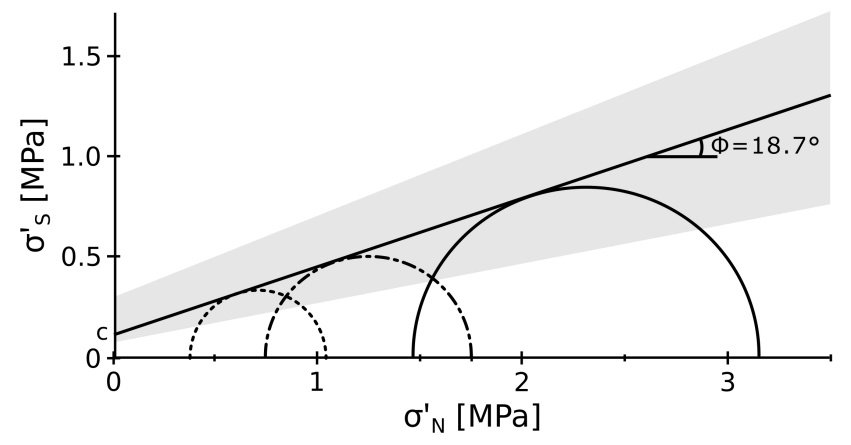

$\sigma_{C}^{\prime}=0.375 \mathrm{MPa} \quad \sigma_{C}^{\prime}=0.750 \mathrm{MPa} \quad \sigma_{C}^{\prime}=1.500 \mathrm{MPa}$

failure envelope range from literature (see Tab. 1)

c: apparent cohesion $=0.117 \mathrm{MPa}$

Figure 2: (a) Stress versus bulk strain $(\varepsilon)$ recorded during the three experiments. All samples show a long trajectory of strain hardening and minor strain softening after peak stress (see also Table 3). (b) Pore pressure $\left(\mathrm{p}_{\mathrm{f}}\right)$ evolutions versus bulk strain $(\varepsilon)$. After onset of deformation compaction lead to pore pressure increases before decreasing pore pressures at larger strains indicate dilatancy. (c) Mohr diagram based on data recorded during the experiments (see Table 3). Derived geomechanical properties (apparent cohesion c and angle of internal friction $\phi$ ) are in good agreement with previously reported values. 


\subsection{Microstructures}

Pores in the clay-rich matrix reflect grain boundaries between individual clay aggregates (Figure 3; see also Desbois et al., 2009; Curtis et al., 2012). We refer to three different foliations, which reflect prevailing orientations of pores and grains (Figures $4 \& 5$ ): (i) $\mathrm{S}_{0}$ is the bedding in deformed and undeformed samples (Figures 1d, 3, 4b \& 5); (ii) $S_{1}$ is a foliation inside the shear zone, oblique to shear zone boundaries (Figure 4c \& 5); (iii) $S_{2}$ is a second foliation inside the shear zone, (sub)parallel to the shear zone boundaries (Figures $4 \mathrm{~d} \& 5$ ) but less-well developed in the sample deformed at a confining pressure of $1.5 \mathrm{MPa}$. Using the nomenclature introduced by Logan et al. (1979) $S_{1}$ corresponds to a P-foliation and $S_{2}$ corresponds to Y-shears.
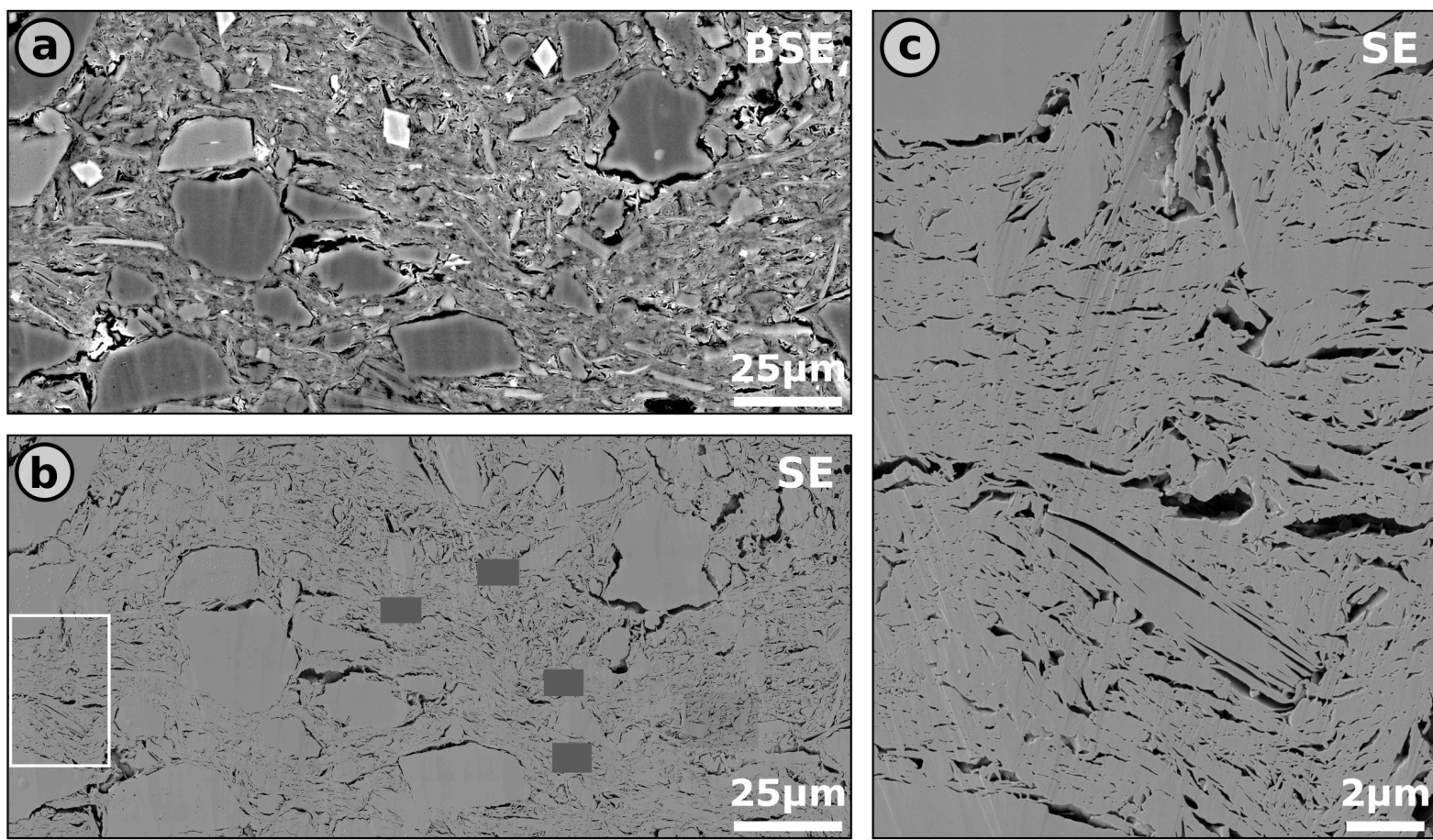

Figure 3: SEM images of undeformed Boom Clay. Pores are supposed to reflect prevailing orientations of pores and grains. Bedding $\left(\mathrm{S}_{0}\right)$ is horizontal in all images. (a) Backscattered electron (BSE) image to investigate microstructures. (b) Same area as in (a) images with secondary electrons (SE) to analyze pores. Dark uniform-grey areas indicate non-imaged areas. White box gives location of (c). (c) Secondary electron image giving details of (b).

Qualitative microstructural investigations of the undeformed sample and the areas of the deformed samples located outside the shear zones (e.g. Figures 3, 4a \& 6) do not show significant visible differences in grain size, grain shape and pore morphology despite the $16 \%$ non-localized strain outside the shear zones. Undeformed and deformed samples display rare examples of bent and broken mica grains (Figure 7a). Furthermore, there are rare fragments of larger micas in the shear zones (Figure 7b). Apart from these occasionally deformed micas, grains are not deformed. The most striking difference is intact dolomite grains in the undeformed sample (Figure 7c) versus substantially dissolved dolomite grains commonly observed in the deformed samples (Figure 7d). Shear zones, commonly between 50 to $100 \mu \mathrm{m}$ thick, have relatively clearly defined boundaries indicated by sharp changes from $S_{0}$ to $S_{1}$ or $S_{2}$, respectively (Figures $4 \mathrm{a}, \mathrm{d} \&$ e) Further microstructures associated with shear zone boundaries are (i) bent micas, occasionally with broken tips (Figures $4 \mathrm{~d} \&$ e) and (ii) trails of individual pyrite grains, probably originating from framboidal pyrite aggregates (Figure 4f) being 
abundant in the undeformed sample and outside the shear zones of deformed samples. $\mathrm{S}_{1}$ covers most of the shear zone. Locally, $S_{1}$ and $S_{2}$ define microlithons with preserved $S_{0}$ and $S_{1}$, respectively. Typical angles for $S_{1}$ and $S_{2}$ relative to $S_{0}$ are respectively $15-25^{\circ}$ and $60^{\circ}$ in the sample deformed at a confining pressure of $0.375 \mathrm{MPa}$ (Figure 5). Angles in the sample confined at $1.5 \mathrm{MPa}$ differ slightly: $40^{\circ}\left(\mathrm{S}_{1}\right)$ and $55^{\circ}\left(\mathrm{S}_{2}\right)$, respectively. Boundaries between $\mathrm{S}_{1}$ and $\mathrm{S}_{2}$ show characteristic microstructures comparable to those observed at shear zone boundaries: bent micas with possible broken tips, and bent clay aggregates (Figure $4 \mathrm{~g}$ ).
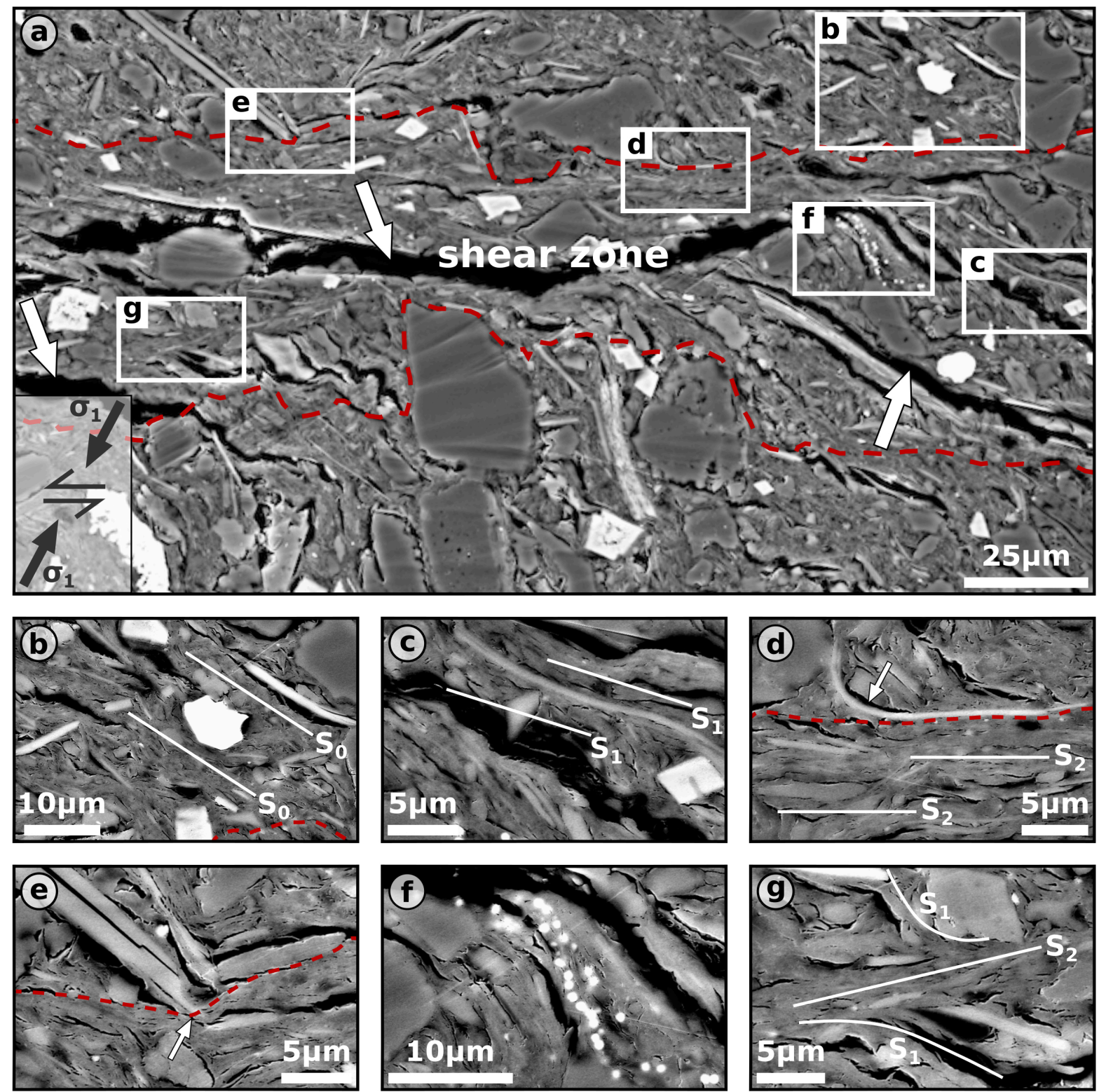

Figure 4: Backscattered electron images of microstructures of deformed samples exemplified at sample confined at $0.375 \mathrm{MPa}$. (a) Overview of shear zone (located between red stippled lines). White boxes indicate location of detail images $\mathrm{b}-\mathrm{g}$. White arrows indicate large cracks typically encountered within the shear zones. Box in the lower left corner indicates relationship between $\sigma_{1}$ and displacement. (b) Bedding $\left(\mathrm{S}_{0}\right)$ is oriented normal to $\sigma_{1}$ and can be observed outside the shear zone. (c) $\mathrm{S}_{1}$ is a foliation (corresponding to a P-foliation sensu Logan et al., 1979) within the shear zone but oblique to its boundaries, hence displacement. (d) $S_{2}$ is a foliation (corresponding to Y-shears sensu Logan et al., 1979) within the shear zone, parallel to its boundaries, hence displacement. White arrow indicates mica grains bent at the shear zone boundary. (e) Fractured mica grain at the shear zone boundary indicated by white arrow. (f) Trail of individual pyrite grains presumably originating from one abundantly-present framboidal pyrite aggregate indicates sense of shear displacement. (g) $S_{1}$ is deflected at the contact to $S_{2}$. 


\section{undeformed sample}

Pores

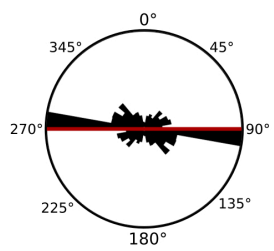

Quartz

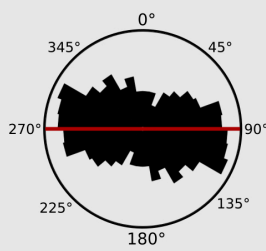

deformed sample

outside the shear zone inside the shear zone outside the shear zone inside the shear zone
\#1
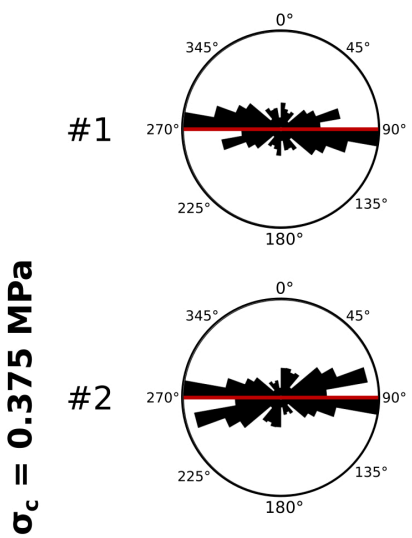

\#3

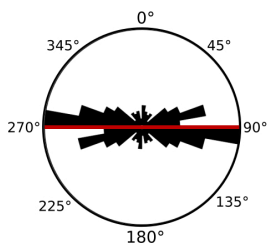

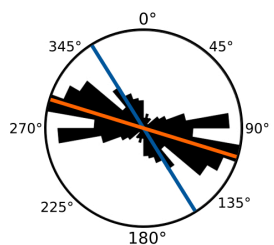
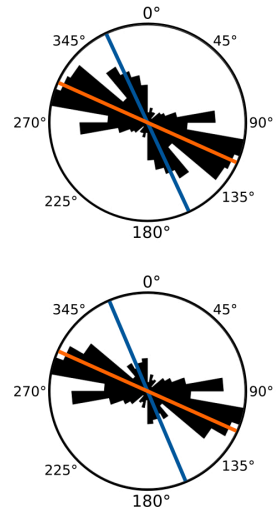
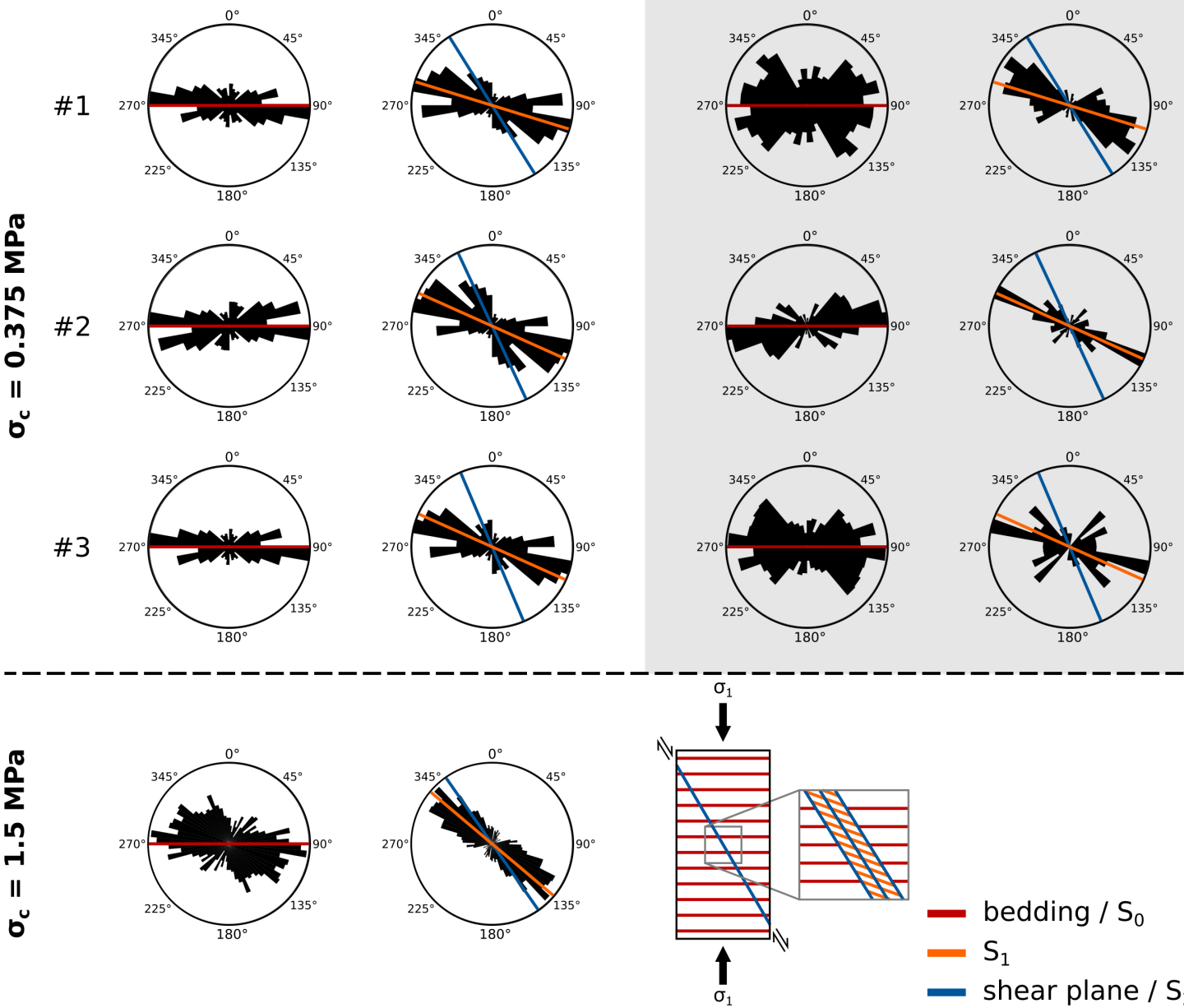

- bedding / $\mathrm{S}_{0}$

- $\mathrm{S}_{1}$

- shear plane / $\mathrm{S}_{2}$

Figure 5: Orientations of pores (left side) and quartz grains (right side) in undeformed (top row) and samples deformed with confining pressures of $0.375 \mathrm{MPa}$ (row $2-4$ ) and $1.5 \mathrm{MPa}$ (bottom row), respectively. Sketch in the bottom right corner indicates relationship of individual foliations with respect to the sample and $\sigma_{1}$, respectively. The bedding / foliation $S_{0}$ (normal to $\sigma_{1}$ ) is clearly visible in undeformed samples and deformed samples outside the shear zones. Within the shear zones, foliation $S_{1}$ (oblique to the shear zones) is clearly visible. This is slightly different compared to foliation $\mathrm{S}_{2}$ (parallel to the shear zones), which can only be identified on the rose diagrams for pores but not on the ones for quartz grains.

Deformed samples display gypsum mineralization within the shear zones (Figure 8). Mineralization, mainly found at shear zone edges, often occupies elongated areas with their long axes being parallel to displacement (the undeformed samples do not contain gypsum). These 
gypsum mineralizations can be cross-cut by micro-cracks (Figures $8 \mathrm{~b} \& \mathrm{c}$ ). Some of the gypsum veins encountered in the sample deformed at $1.5 \mathrm{MPa}$ confining pressure are curved along a central line parallel to the shear direction (Figure 8c) suggesting syndeformational growth.

Furthermore, samples split along the shear plane locally show slickensides and imbricated, flaky clay aggregates aligned parallel to shear displacement (Figures 9a \& b).
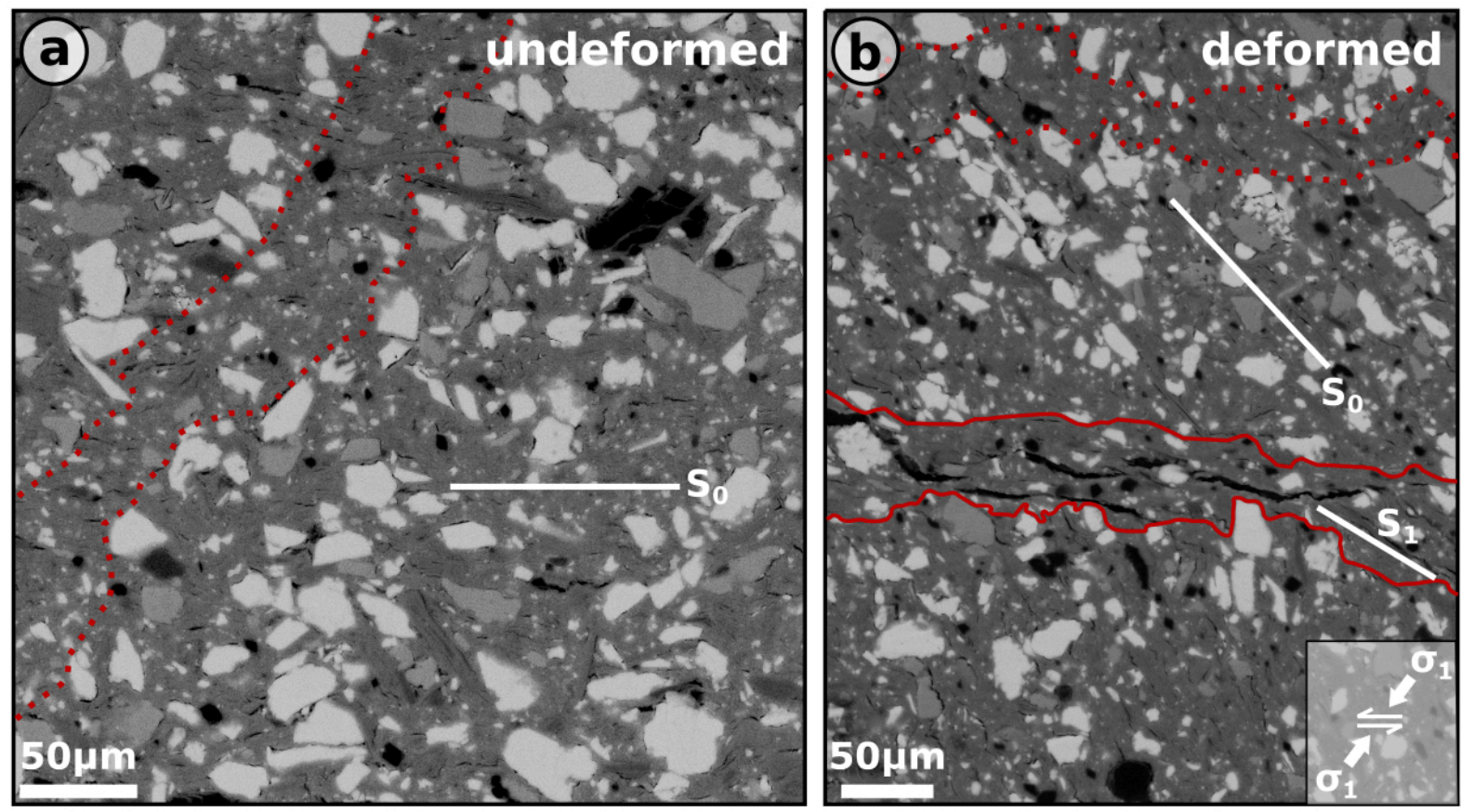

Figure 6: Backscattered electron images of the undeformed (a) and the deformed sample confined at $0.375 \mathrm{MPa}$ (b). The shear zone (left image; located between the two solid red lines) is apparently characterized by smaller grain sizes than the bulk sample (see also Figures $10 \mathrm{a} \& \mathrm{~b}$ ). However, these zones with smaller than bulk sample grain sizes can be observed at other locations in the deformed sample and the undeformed sample (located between dotted red lines). These zones in undeformed and deformed samples can have comparable angles with respect to bedding $\left(\mathrm{S}_{0}\right)$.

To study particle and pore size distributions "sieve curves" were generated (Figure 10). For this, quartz and feldspar grains as well as pores were first sorted according to their size in increasing order. In a second step, cumulative area percent (i.e. contribution of all grains/pores with respect to grains/pores smaller or equal a specific size compared to the overall area occupied by this phase) were plotted against the grain size. Particle and pore size distributions are different depending on their location in- or outside the shear zone: grains inside the shear zone plot left of grains outside the shear zone (Figures 10a \& b). This implies that grains inside the shear zone are smaller than outside the shear zone. Furthermore, the grain size distribution derived from the undeformed sample plots in-between the distributions obtained from grains in- and outside the shear zone, respectively. Pore size distributions display the opposite pattern (Figure 10c) as pores inside the shear zone plot right of pores outside the shear zone, i.e. pores inside the shear zone tend to be larger than those outside.

The quantitative observation of apparently smaller grain sizes within the shear zone is supported by qualitative microstructural investigations (Figure 6). We note here that undeformed samples also show elongated regions characterized by smaller grain sizes than the surrounding matrix (Figure 6). 

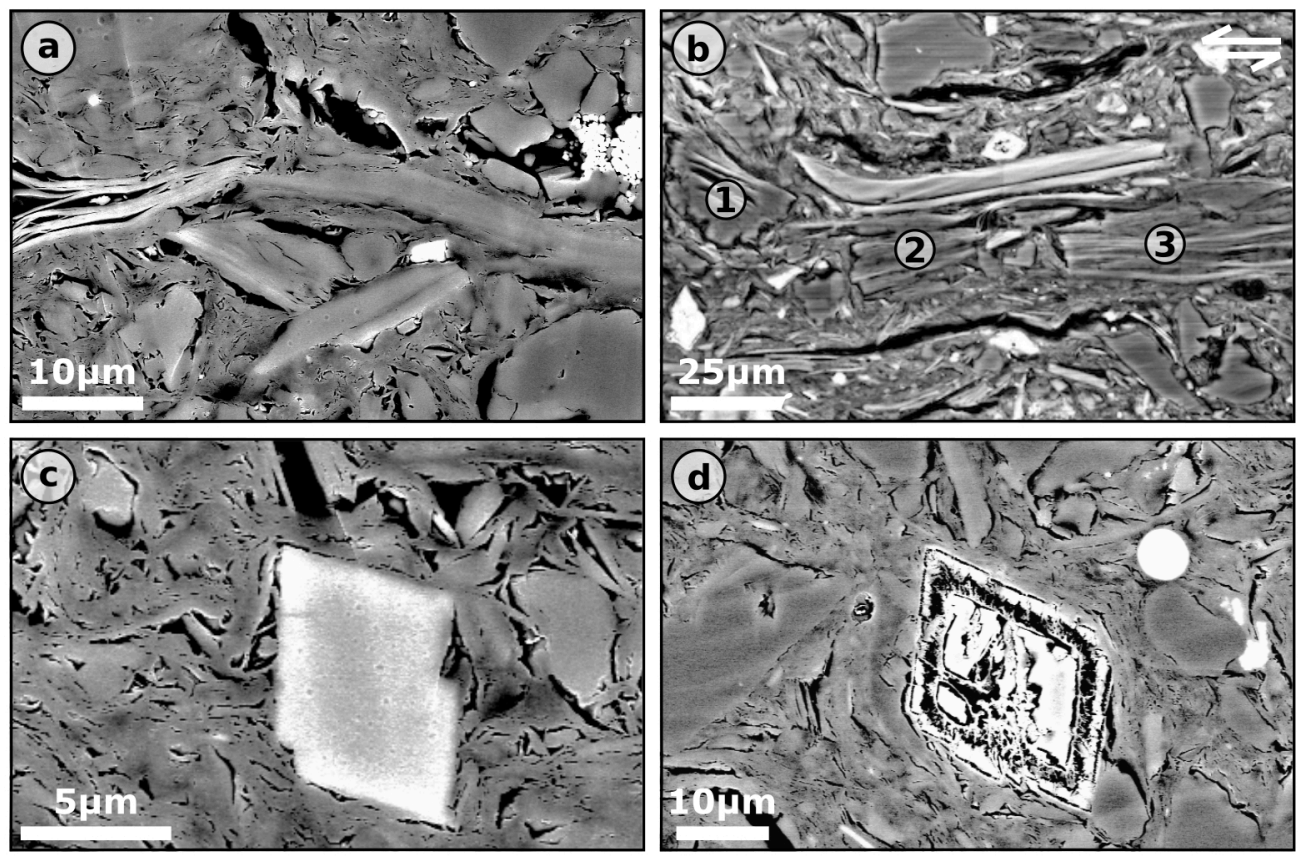

Figure 7: Backscattered electron images of microstructures. (a) Rare example of deformed mica grains in the undeformed samples. (b) Dolomite grains in the undeformed sample are not dissolved. (c) Shear zone of sample deformed at 1.5 MPa confining pressure containing three mica fragments originating potentially from a single, large grain. (d) Dolomite grains in deformed samples are commonly heavily dissolved.

Measured SEM-visible porosities, based on about $10^{6}$ segmented pores, systematically decrease in the following order (Table 4$)$ : undeformed sample $(\sim 13.7 \%)$, deformed sample, outside the shear zone $(\sim 9.4 \%)$ and deformed sample, inside the shear zone $(\sim 7.1 \%)$. Furthermore, pores are more elongated in the same order (Figure 11). At the scale of our investigations, the relative error on the porosity measurement from an ideal representative infinite area is about $12 \%$ for the undeformed sample, ranges between 11 and $15 \%$ areas outside the shar zone of deformed samples and 14 to $35 \%$ for shear zones, respectively (Table 4). The higher relative errors determined within shear zones are explained by the relatively small area of shear zone available in a single BIB-cross section, compared to the area covered located outside the shear zone.
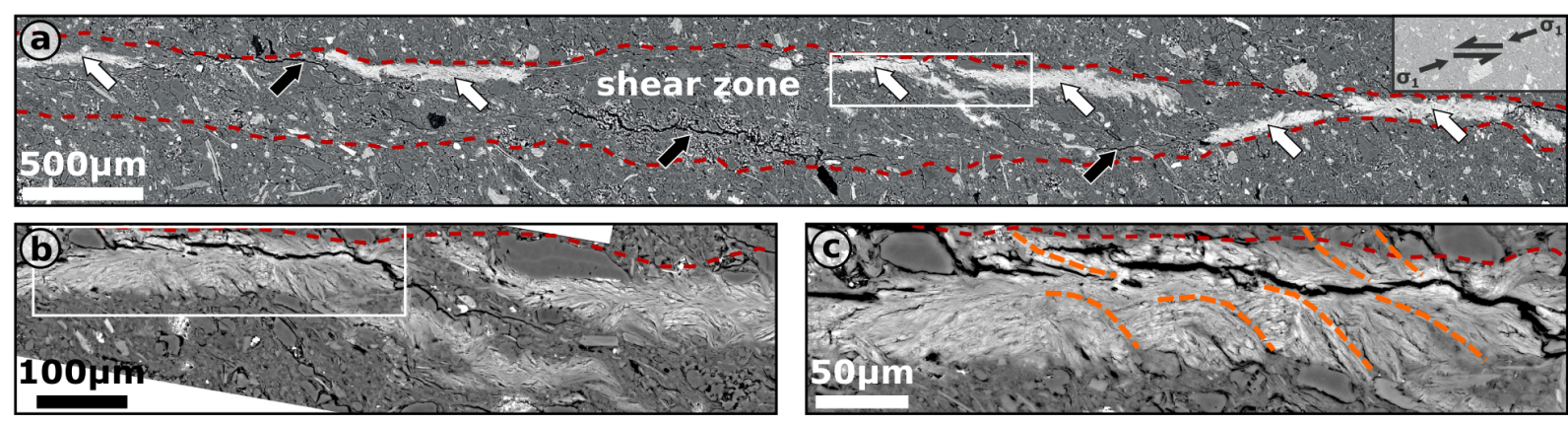

Figure 8: Backscattered electron images of deformed sample confined at $1.5 \mathrm{MPa}$. (a) Black arrows indicate large cracks within the shear zone. White arrows highlight areas within the shear zone mineralized by gypsum. White box gives location of (b). Arrows in the upper right corner indicate relationship between $\sigma_{1}$ and displacement. (b) Detail of (a). White box gives location of (c). White areas indicate non-imaged areas. (c) Gypsum minerals are bent (indicated by stippled orange line) pointing to syndeformational growth. 
Whereas there are micro-cracks observed in the undeformed sample, deformed samples contain micro-cracks outside the shear zones oriented parallel to $S_{0}$ (Figure 12). Within the shear zones, there are large cracks with orientations varying between $S_{1}$ and $S_{2}$ (Figures 4a, 8 \& 12).
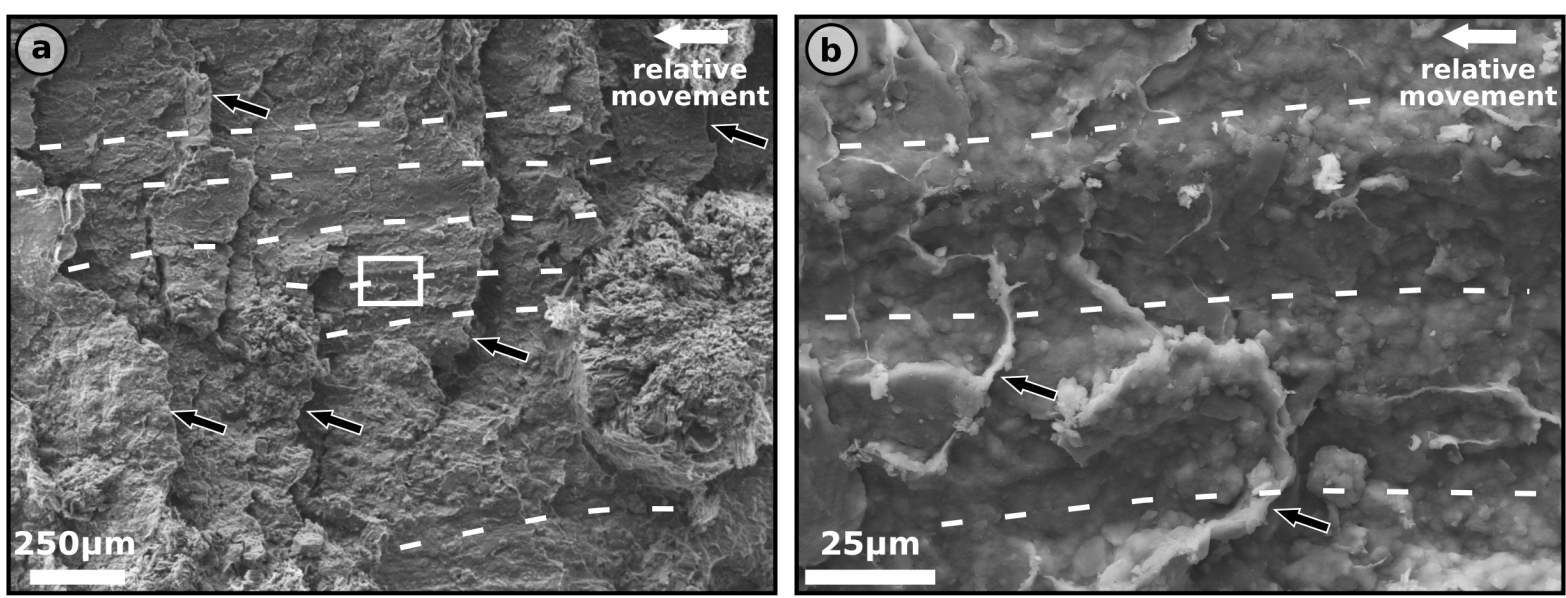

Figure 9: Backscattered electron images of deformed sample confined at 0.375 MPa split along the shear zone (i.e. view is on top of the shear plane). Relative movement of displayed plane is to the left side as indicated by white arrows in the upper right corner. (a) Overview of shear plane with slickensides, striations (white stippled lines) and imbricated clay aggregates (black arrows). White box indicates location of (b). (b) Detail of (a).

Table 4: Characteristics of analyzed areas for porosity investigations.

\begin{tabular}{|c|c|c|c|c|c|c|c|c|c|}
\hline \multirow[t]{4}{*}{ Sample } & \multirow[t]{4}{*}{$\mathbf{U S}^{\mathbf{a}}$} & \multicolumn{8}{|c|}{$\mathbf{D S}^{\mathbf{b}}$} \\
\hline & & \multicolumn{6}{|c|}{$\sigma_{c}^{\prime}=0.375 \mathrm{MPa}$} & \multicolumn{2}{|c|}{$\sigma_{c}^{\prime}=1.5 \mathrm{MPa}$} \\
\hline & & \multicolumn{2}{|c|}{$\# 1$} & \multicolumn{2}{|c|}{$\# 2$} & \multicolumn{2}{|c|}{ \#3 } & & \\
\hline & & OSZc & ISZd $^{\mathbf{d}}$ & OSZ & ISZ & OSZ & ISZ & OSZ & ISZ \\
\hline $\begin{array}{l}\text { Size } \quad \text { of } \\
\text { analyzed area } \\
{\left[\mu \mathrm{m}^{2}\right]}\end{array}$ & 120,546 & 120,725 & 35,647 & 55,801 & 35,401 & 30,878 & 3,015 & 1,997 & 2,444 \\
\hline Porosity [\%] & 13.72 & 8.35 & 6.49 & 10.46 & 8.13 & 10.54 & 8.53 & 8.20 & 5.40 \\
\hline $\begin{array}{l}\text { Relative error } \\
{[\%]}\end{array}$ & 11.61 & 10.41 & 20.47 & 10.89 & 34.81 & 15.60 & 13.47 & / & / \\
\hline
\end{tabular}

\section{Discussion}

\subsection{Possible artefacts due to sample preparation and experimental setup}

In our experiments, the samples experienced the following sequence of perturbations: (i) stress unloading after coring and slight dehydration during the packing in Al-barrier foils at URF; (ii) water migration and swelling while stored in Al-barrier foils; (iii) swelling and compaction during the saturation and consolidation before the triaxial test; (iv) stress unloading 
after the experiments; (v) slow drying after deformation; (vi) sawing and mechanical polishing during subsampling for BIB-polishing; (vii) high vacuum during BIB-polishing and SEM analyses; (viii) high energy electron beam during SEM analyses. It is known that drying of undeformed Boom Clay leads to shrinkage and slight changes of the pore fabric together with shrinkage of swelling clay aggregates (Hemes et al., 2013). We note that in addition, deformed samples may dry and shrink differently outside and inside the shear zones.

a

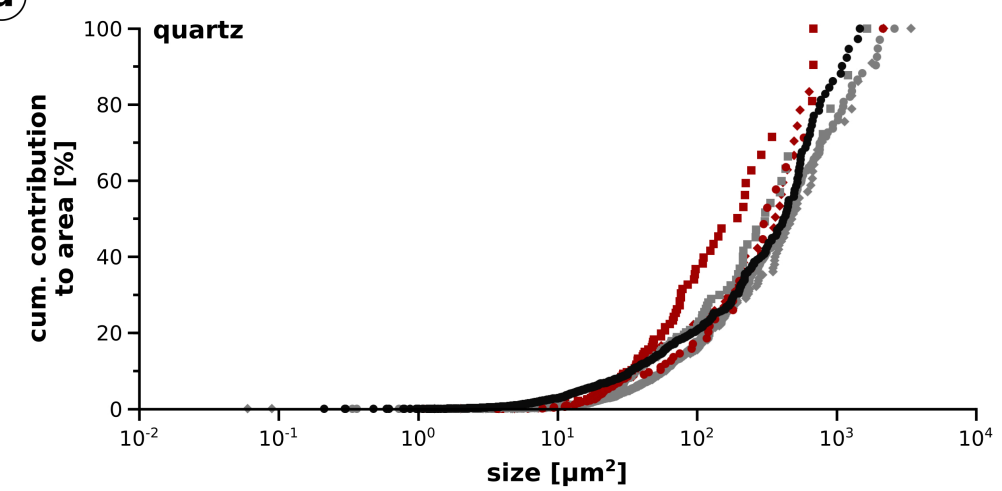

(b)

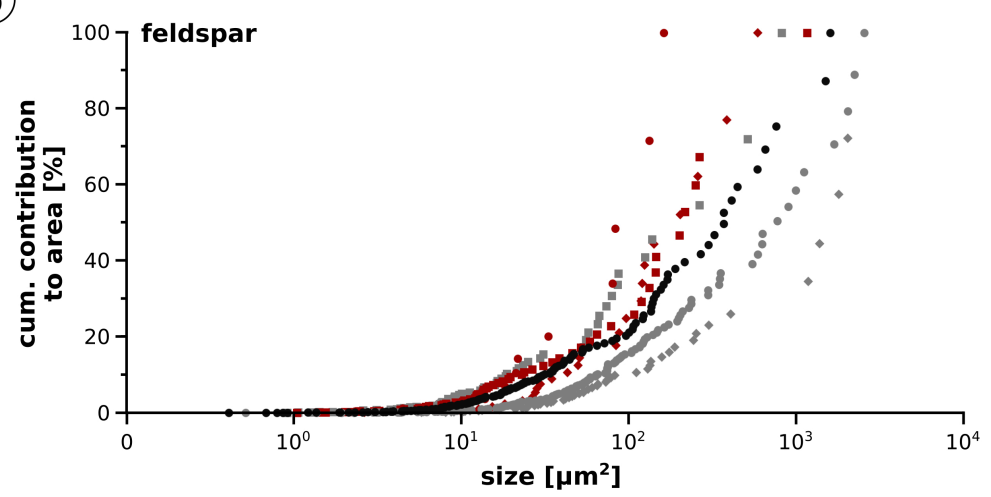

(c)

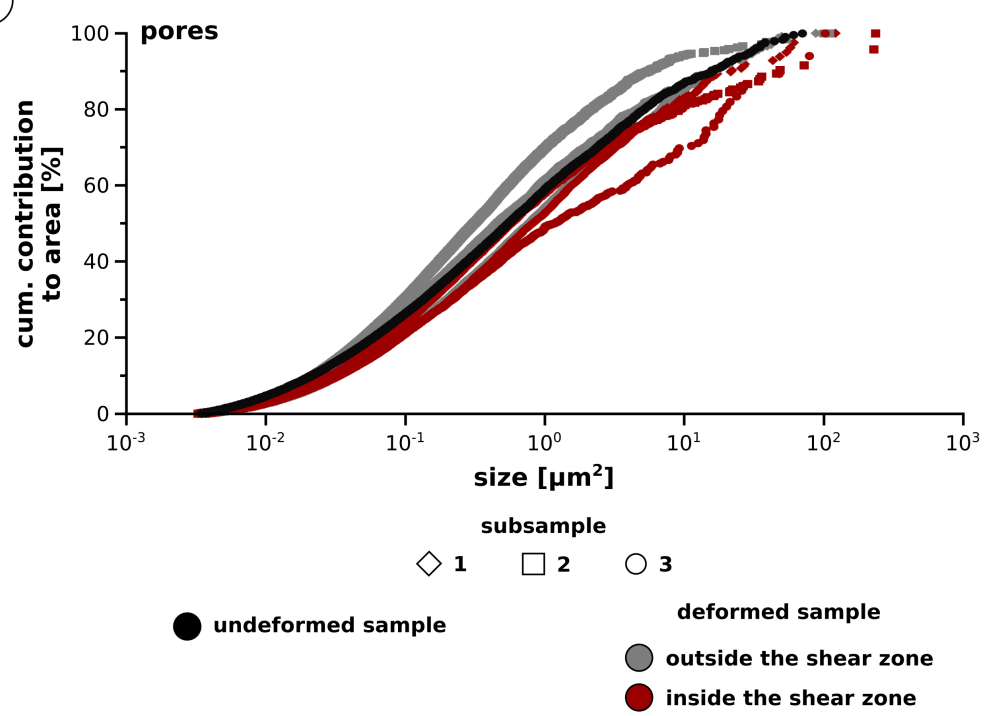

Figure 10: "Sieve curves" to investigate grain (a: quartz; b: feldspar) and pore (c) size distributions performed on three subsamples from the undeformed sample and the deformed sample confined at 0.375 $\mathrm{MPa}$. To generate sieve curves grains/pores were sorted according to their size in increasing order before the contribution of all grains/pores with respect to grains/pores smaller or equal a specific size compared to the overall area occupied by this phase (i.e. the cumulative area percent) was plotted against the grain size. 
Pre-existing micro-cracks are expected to have closed during the consolidation phase, which implies that any micro-cracks must have been activated during or after the experiment (Bésuelle et al., 2014). Current analyses indicate that high vacuum during BIB polishing does not further reduce the water content (Anne Oelker pers. comm. 2018) suggesting that micro-cracks are not formed during BIB-polishing. Bedding-parallel cracks are present in deformed but absent in undeformed samples (Figure 12) which strongly suggests that their formation is related to unloading after the experiment. In contrast, micro-cracks encountered within the shear zones (Figures $4 \mathrm{a}, 8$ \& 12), most likely formed during deformation as it is expected for the slightly overconsolidated Boom Clay (e.g. Horseman et al., 1987; Horseman et al., 1993) and indicated by decreasing pore pressures for strains larger than $6 \%$ (samples confined at 0.350 and $0.750 \mathrm{MPa}$, respectively) and $\sim 16 \%$ (sample confined at $1.5 \mathrm{MPa}$ ), respectively (Figure 2b). However, it cannot be excluded that the initial width of these micro-cracks increased during unloading. Consequently, we expect our SEM images to be slightly different from the in-situ images. Further application of the cryo-BIB-SEM method (Desbois et al., 2009; Desbois et al., 2014) on extremely well-preserved Boom Clay samples quenched in liquid nitrogen only a few minutes after opening the core case are currently in progress to understand and evaluate in detail the damages induced by stress unloading after sample collection at the URF and subsequent drying (Desbois et al., 2017b).
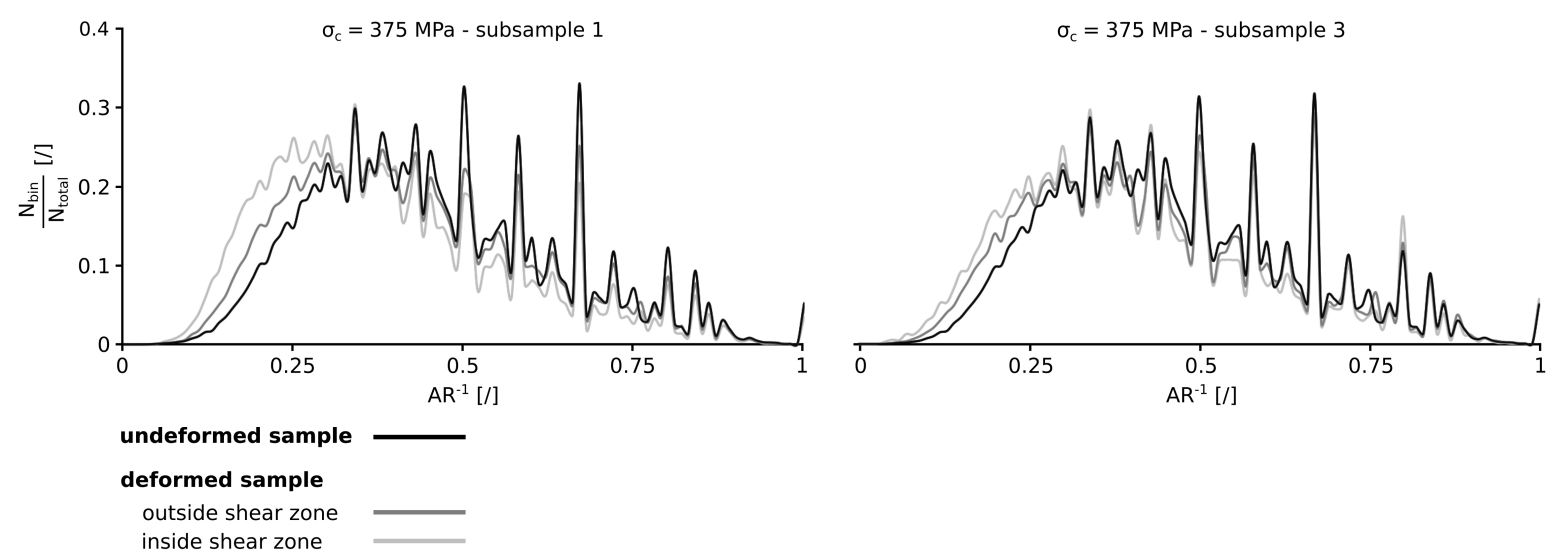

Figure 11: Investigation of pore elongation in two subsamples of the deformed sample confined at 0.375 $\mathrm{MPa}$. The $\mathrm{x}$-axis shows the inverse axial ratio $\left(\mathrm{AR}^{-1}\right)$ of the pores' bounding ellipses. The inverse axial ration (length of short axis divided by length of long axis) has been chosen to ensure derived values range between 0 (infinitively elongated pore) and 1 (sphere). To produce the plot $\mathrm{AR}^{-1}$ was binned (bin size: $0.01)$. The $y$-axis gives the frequency of pores falling within a specific bin $\left(\mathrm{N}_{\text {bin }}\right)$. To facilitate comparability between individual samples differing by the total amount of investigated pores, frequencies have been normalized by the total amount of pores within a sample. In fact, resulting curves are probability density distributions (i.e. the integral of each curves equals 1). Results reveal that curves are systematically (undeformed sample - area of deformed sample located outside the shear zone - shear zone of deformed sample) shifted towards the left side. This observation implies that distributions plotting more towards the left side reflect more elongated pores. Please note: this does not imply that the pores' long axes lengthen; a - most likely compaction-induced - shortening of the pores' short axes is sufficient to yield this result.

Striking differences between undeformed and deformed samples are (i) intact and commonly dissolved dolomite grains (Figures 7c \& d) and (ii) gypsum mineralization only present in deformed samples (Figure 8). It appears likely that both observations are related to the use of di-ionized water providing oxygen instead of synthetic Boom Clay pore fluids to re-saturate samples before the experiment: under these conditions, dissolved oxygen facilitated pyrite dissolution, which provided sulfate ions, increased pore fluid acidity and enabled associated 
dolomite dissolution. Subsequently gypsum precipitated (e.g. Ritsema and Groenenberg, 1993; and references therein).

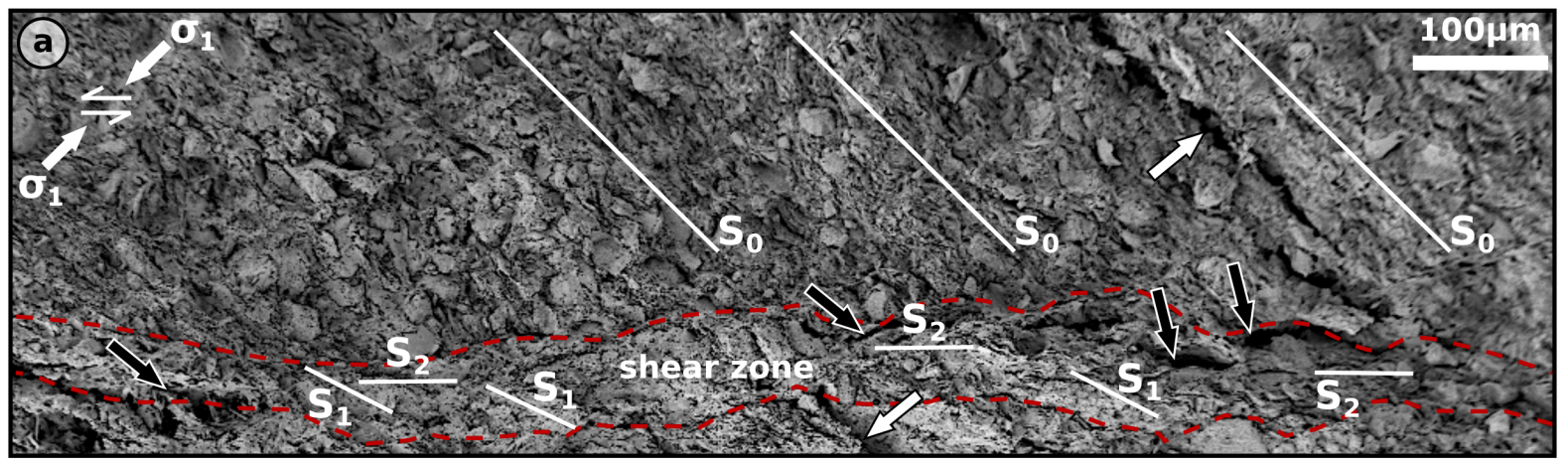

Figure 12: Backscattered electron image of sample broken across the shear zone (same orientation as BIB-polished samples), i.e. view is perpendicular to the shear plane. Sketch in the upper left corner gives relationship between $\sigma_{1}$ and shear displacement. Shear zone is located between the two stippled red lines. White lines give orientation of foliation $S_{0}$ (bedding), $S_{1}$ (oblique to shear zone) and $S_{2}$ (parallel to shear zone). White arrows indicate joints parallel to $S_{0}$ and black arrows give cracks typically located within the shear zone with orientations intermediate or equal to $S_{1}$ and $S_{2}$, respectively.

\subsection{Pore pressure evolution and associated shear zone dilatancy}

Pore pressure drops of samples confined at 0.375 and $0.750 \mathrm{MPa}$ (Figure 2b) indicate dilatancy, i.e. the formation of micro-cracks observed within the shear zones (Figures 4a, 8 \& 12). Dilatancy before peak stress is characteristic for moderately to highly overconsolidated clays and typically observed in Boom Clay (e.g. Horeseman et al., 1987; Baldi et al., 1991a; Baldi et al., 1991b; Dehandschutter et al., 2005b and references therein). The absence of pore pressure drops before failure and only moderately declining pore pressures after failure recorded for the sample confined at $1.5 \mathrm{MPa}$ (Figure 2b) are probably related to the syndeformational mineralization of gypsum veins (Figure 8; see also section 4.1). Under this assumption, syndeformational dilatancy was counteracted by syndeformational gypsum mineralization. However, it remains elusive if micro-cracks cross-cutting zones of gypsum mineralization (Figure 8c) are of syndeformational origin or result from unloading.

\subsection{Mechanisms of deformation}

The geomechanical behaviour exhibited by deformed samples with stress-strain curves displaying trajectories of strain hardening, poorly-defined peak stresses and subsequent onsets of minor strain softening (Figure 2a) is characteristic for plastic materials (Wood, 1990). Furthermore, this slight brittleness in combination with slight syndeformational dilation resulting in observed hybrid fractures (i.e. dilatant shear fractures, Figures 4 a, 8 \& 12; Ingram and Urai, 1999), is typical for overconsolidated mudrocks (Lupini et al., 1981; Laurich et al., 2017). However, while this behaviour has been observed previously (e.g. Baldi et al., 1991a; Baldi et al., 1991b), Boom Clay deformed in triaxial experiments and undrained conditions commonly displays better defined peak stresses followed by pronounced strain-softening (e.g. Horseman et al., 1987; Coll, 2005). 
In general, geomechanical parameters (apparent cohesion, angle of internal friction; Figure 2c) derived from mechanical data recorded during the experiments are in good agreement with previous findings (Table 1; e.g. Horseman et al., 1987; Baldi et al., 1991a; Baldi et al., 1991b; Coll, 2005). Furthermore, macro- and microstructural observations such as shear zone thickness and its angle to $\sigma_{1}$ (Horseman et al., 1987; Baldi et al., 1991a; Baldi et al., 1991b; Coll, 2005), presence of micro-cracks (e.g. Sultan et al., 2010; Yu et al., 2012), preferred particle alignment and bent phyllosilicates (Al-Mukthar et al., 1996; Djéran-Maigre et al., 1998) and slickensides (Horseman et al., 1987) have been described in previous experimental studies on Boom Clay. These microstructures of experimentally deformed Boom Clay are comparable with the ones resulting from ring and biaxial shear experiments achieving high strains in uncemented, finegrained, phyllosilicate-rich material (Morgenstern and Tchalenko, 1967; Wu, 1978; Haines et al., 2009; Haines et al., 2013; Ikari et al., 2015).

About $80 \%$ of bulk strain is accommodated outside the shear zone (see section 3.1). As indicated by syndeformational pore pressure increases (Figure $2 \mathrm{~b}$ ), non-localized deformation outside the shear zone resulted in porosity reductions, which in case of SEM-visible porosities are in the order of $23-40 \%$ (Table 4). Furthermore, pores size distributions outside the shear zones of deformed samples suggest smaller pore sizes compared to the undeformed sample (Figure 10c). By taking the absence of microstructural differences between the undeformed sample and the areas of diffuse strain into account, the main deformation mechanism was compaction of pores within the matrix.

Considering that maximum displacement along the shear zone is up to $4 \mathrm{~mm}$ (Figurer $1 \mathrm{a} \& \mathrm{~b}$ ) and that the shear zone thickness is in the order of 50 to $100 \mu \mathrm{m}$ (Figures 5, 6 and 7), the maximum shear strain in the shear zone is in the range of 40 to 80 . While outside the shear zone deformation only resulted in pore collapse, the shear zones themselves have also been affected by porosity reduction (Table 4) but display in addition further deformation-related microstructures such as bent and occasionally broken phyllosilicates (Figures 4d \& e) and preferred particle alignment having resulted in mineral and pore fabrics with well-developed $S_{1}$ and $S_{2}$ foliations oblique to the bedding (Figure 4).

Microstructures of non-phyllosilicate minerals do not show any evidence of fragmentation such as angular, chipped or abraded edges (e.g. Passchier and Trouw, 2005) Furthermore, their grain size distribution is apparently not power-law distributed (Figure 13), which - if present would suggest grain fragmentation (Marone and Scholz; 1989). Whereas there is missing evidence for (abundant) particle comminution, the presence slickensides (Figure 9), two foliations $\left(\mathrm{S}_{1}\right.$ and $\mathrm{S}_{2}$; Figures $\left.4 \& 5\right)$ clearly reflecting reorientation of larger clastic particles and pores (i.e. clay minerals constituting the matrix) in combination with the dominance of frictionally weak phyllosilicates (Table 1) and the associated low angle of internal friction (Table 2; Figure 2c) argue that strain within the shear zones was accommodated by granular flow: sliding between low frictional, platy clay particles (Lupini et al., 1981). Additionally, normal stresses of this specific experimental setup aiming to simulate shallow-depth conditions as well as normal stress generally used to approach geotechnical problems are too low to foster particle comminution (for a detailed discussion see Tembe et al., 2010). Consequently, formation of $S_{1}$ and $S_{2}$ was achieved by independent particulate flow (grain boundary sliding) and particle rotation (see Morgenstern and Tchalenko, 1967; Borrodaile et al., 1980). This promoted the long 
axes of platy phyllosilicates and of other elongated particles to align in the direction of the XY plane of finite strain (Moore and Lockner, 2004; Moore and Lockner 2007).
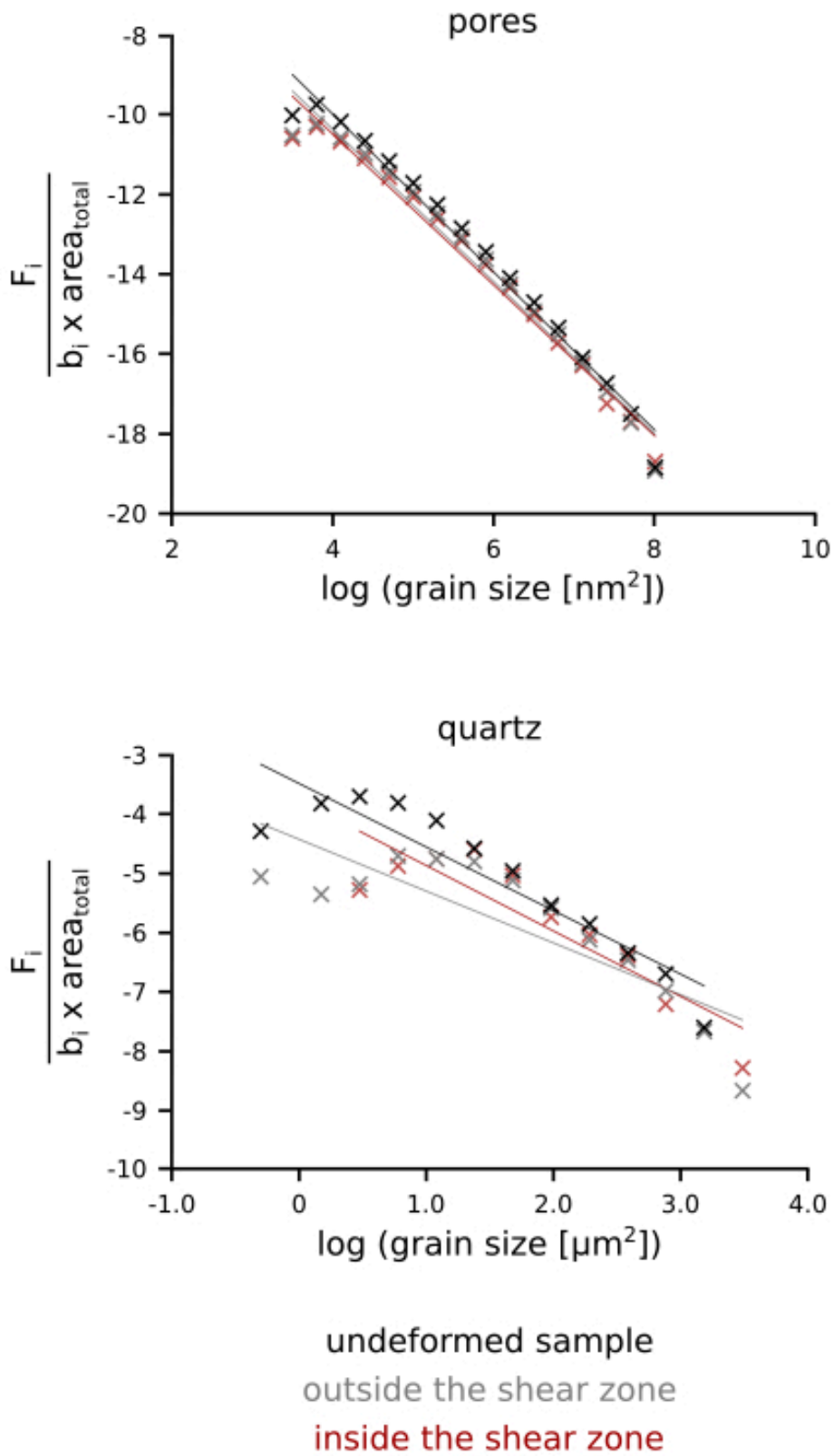

Figure 13: Pore-law analyses of pore (a) and quartz grain (b) sizes from deformed sample confined at $0.385 \mathrm{MPa}$. For methodological details refer to Hemes et al. (2013). While pore sizes are power-law distributed, as it can be expected for clay-rich materials (Desbois et al., 2009; Klaver et al., 2012; Houben et al., 2013), quartz grain sizes are not power-law distributed.

In contrast to the usually framboidal pyrite aggregates in undeformed Boom Clay and in deformed samples outside the shear zone (this study and Hemes et al., 2013), trails of single pyrite grains (Figure 4f) support the presence of independent particulate flow within the shear zones. In addition, bent micas at shear zones boundaries (Figure $4 d$ ) and between $S_{1}$ and $S_{2}$ point to intracrystalline deformation. However, at the resolution of SEM images, the internal structure of the dominating clays-sized (i.e. $<2 \mu \mathrm{m}$ ) particles is not accessible. 
To identify deformed clay aggregates, nanoscale investigations using transmission electron microscopy (TEM) would be necessary (Lee et al., 2003; Laurich et al., 2014; Schuck et al., 2018). However, comminution of clay particles appears unlikely, because (i) clay minerals with aligned (001) basal planes present in amounts significantly smaller than in this study are able to drastically reduce a material's frictional strength (e.g. Schleicher et al., 2010; Morrow et al., 2017) and (ii) the typical grain size of clay minerals is so small that it is easier for a fracture to propagate along grain boundaries than to break grains (cf. Haines et al., 2013). While these arguments oppose fragmentation of clay-sized phyllosilicates, larger micas with broken tips located at shear zone (Figure $4 \mathrm{e}$ ) and $\mathrm{S}_{1} / \mathrm{S}_{2}$ boundaries, respectively, indicate fracturing. These observations in combination with fragments of a larger mica grain (Figure 7b), interpreted as boudinage in microlithons, indicate that larger phyllosilicates can deform in a brittle manner, when the grain size is too large to accommodate particle rotation and sliding mechanisms. Widened and/or offset cleavage planes observed in larger mica grains suggest that some of these particles may be delaminated when they are deformed in the shear zone.

With their formation being related to syndeformational grain and pore reorientation, the orientation of $S_{1}$ and $S_{2}$ with respect to shear zone boundaries suggest a consecutive formation: $\mathrm{S}_{1}$ (P-foliation), oblique to shear zones boundaries, developed at low strains (e.g. Cladouhos, 1999a; Cladouhos, 1999b; Blenkinsop, 2000; Haines et al., 2013). Higher strains resulted in the formation of $S_{2}$ (Y-shears) parallel to shear zones boundaries (e.g. Blenkinsop, 2000; Jessel et al., 2009; Haines et al., 2013). Owing their identical orientation, slickensides observed along fractured shear zones (Figure 9) are interpreted to correspond to the $S_{2}$ foliation. Following Haines et al. (2009), Haines et al. (2013) and Ikari et al. (2015), $S_{2}$ are interpreted to be active shear surfaces where shear strain localized.

Pore size distributions and qualitative microstructural investigations demonstrate that syndeformational dilatancy localized within shear zones: "sieve curves" indicate that pores in the shear zone tend to be larger compared to the undeformed sample and areas located outside the shear zones of deformed samples (Figure 10c). This observation is especially significant for the $20-30 \%$ of largest pores. Furthermore, large cracks (up to several 100s $\mu \mathrm{m}$ long; e.g. Figures 4a, 8 \& 12) are only present within shear zones (bedding-parallel cracks of similar dimension are encountered outside the shear zone but represent an artefact as discussed above, Figure 12; see section 4.1). Similar observations of shear zones facilitating dilatancy in otherwise non-dilatant claystones have been described for the also slightly overconsolidated Opalinus Clay, too (Laurich et al., 2014; Laurich et al., 2017).

As expected for the large strains achieved in the shear zones (e.g. Dewhurst et al., 1996), porosity is stronger reduced (Table 4) and pore morphologies are more elongated (Figure 11) compared to the areas located outside the shear zone. These changes in response to applied axial shortening are further enhanced by the dominating deformation mechanisms in combination with the predominance of platy phyllosilicates: particle rotation and sliding mechanisms promoted the alignment and the stacking of clay aggregates along their long axes (i.e. promoting pores with long aspect ratios between platy clay similarly oriented aggregates; Desbois et al. 2009; Curtis et al. 2012). Compared to $S_{1}, S_{2}$ displays barely visible porosity at the resolution of SEM (Figure 4g). These small porosities suggest that the pore fabric accommodates the high strains along the Y-shears by minimizing the inter-particle porosity between clay aggregates. 


\subsection{Strain localization in experimentally deformed Boom Clay at low confining pressures: a conceptual model}

In addition to identifying acting deformation mechanisms, it is equally important to unravel how and why strain localized to understand the rheology of investigated Boom Clay samples. In the following we discuss constraints on strain localization and propose a conceptual model for the strain localization in experimentally deformed Boom Clay at low confining pressures.

Boom Clay is a complex heterogeneous material. However, in order to understand its bulk geomechanical behaviour and how it accommodates strain, it can, in a first approximation, be considered as a two-phase material composed of strong phase (non-phyllosilicates) embedded within a matrix of a weak phase (phyllosilicates). The proportion of hard to soft phases in deformed samples (1:2; Table 1) and the spatial distribution of the hard phase (dispersed in the matrix) imply that the soft phase (i.e. the matrix) accommodates most of the strain, as the hard phase does not act as a load-bearing framework, i.e. the macroscopically observed deformation behaviour is determined by the amount of hard particles (e.g. Lupini et al., 1981; Handy, 1994; Jessel et al., 2009). In our deformed samples the grain size of non-clay minerals in the shear zone is smaller than outside the shear zone (Figures $6,10 \mathrm{a} \& \mathrm{~b}$ ). There are two possible explanations for this observation: (i) cataclastic processes leading to particle comminution (e.g. Marone and Scholz, 1989; Desbois et al., 2017a) and (ii) shear zone formation in zones without large grains. While the first option has been excluded based on missing direct (e.g. fractured grains) and indirect (grain sizes of rigid particles do not display power law distributions; Figure 13) evidences (see section 4.3), the second option appears to be the likely one.

In a two-phase material the strength contrast between clasts and matrix promotes strain localization, i.e. a shear zone evolves in the low-strength phase (Handy, 1994; Jessel et al., 2009; Rybacki et al., 2014; Nardini et al., 2018). However, while on macroscale strain localizes in shear zones, foliations $S_{1}$ and $S_{2}$, oblique and parallel to shear zone boundaries, respectively, indicate that strain localization within the shear zones is heterogeneous, too. Considering the two-phase model employed to describe strain localization, the low-strength phase hosts the shear zone. Consequently, heterogeneous strain accommodation within the shear zones is not governed by a strength contrast but needs a different mechanism: although particles in undeformed Boom Clay display a bedding (Figures 3, 5 \& 6a), they are not perfectly aligned. Once a shear zone localizes, governed by the strength contrast between the hard and the soft phase, and displacement starts to accommodate, tips of phyllosilicates become entangled and particles start to rotate before they subsequently slide along their grain boundaries, which results in foliation $S_{2}$ at higher strains. The harder phases also rotate but are rheologically passive (Handy, 1990). This "geometric softening" within the low-viscosity phase requires sufficient porosities to enable particle rotation. This interpretation implies that the perception of strain localization depends on the scale of observation: while strain localization is governed by geometric constraints on the nano- to microscale (i.e. scale of matrix-forming phyllosilicates), it is governed by viscosity contrasts at the meso- to macroscale (i.e. scale of shear zone thickness, Figure 6, to bulk sample scale).

The assumption that strain localizes in zones with a lower fraction of large, hard particles is supported by such bands present in every orientation in the undeformed sample and outside the shear zones of deformed samples (Figure 6). In frictional materials the orientation of shear 
zones is controlled by the material's Coulomb angle (Guo \& Stolle, 2013). Our results show how the spatial distribution of strong and weak phases with respect to $\sigma_{1}$ facilitates this (Lupini et al., 1981; Handy, 1994; Shen \& Lissenden, 2005; Jessel et al., 2009). The observed small variations in the orientation of the shear zone with respect to $\sigma_{1}$ (Figure 1c) might reflect the initial heterogeneous distribution of strong particles. However, to quantify this process, it is necessary to investigate larger areas at high resolution. In addition, strain localization in our samples is affected by (i) friction between pistons and sample, and (ii) the cylindrical symmetry of the specimen (Viggiani \& Hall, 2008).

\subsection{Comparison of microstructures from experimentally and naturally deformed Boom Clay}

Deformation-related microstructures observed in naturally deformed Boom Clay comprise shear bands with and without slickensides, hybrid shear fractures and cracks (Dehandschutter et al., 2005a; Dehandschutter et al., 2005b). Furthermore, these discontinuities are associated with reduced porosities and phyllosilicates oriented parallel to displacement. These microstructures are comparable to the ones generated during the experiments presented in this paper. Furthermore, we expect that BIB-SEM observations of natural shear zones in Boom Clay will also show similar microstructures.

Microstructures in our experiments are comparable to those generated during construction processes at the URF at Mol-Dessel, where excavation lead to hybrid failure, slickenside formation and reorientation of phyllosilicates manifested in an excavation damaged zone (Dehandschutter et al., 2002; Dehandschutter et al., 2004, Mertens et al., 2004). While in situ confining pressure and differential stresses are inferred to be around $1.9 \mathrm{MPa}$ and $0.5 \mathrm{MPa}$, respectively, excavation promoted differential stress to increase until this artificial disturbance resulted in failure at a differential stress in the order of 2.4 MPa (Dehandschutter et al., 2004). This differential stress at failure is on a first order approximation similar to that recorded during our experiments $\left(0.685<\sigma_{\text {diff }}<1718 \mathrm{MPa}\right.$; Table 3$)$.

In this first look then, comparisons between Boom Clay deformed artificially (i.e. during experiments and excavation) and naturally indicate that deformation mechanisms inferred in this study (i) are representative of those occurring during URF excavation and in nature at low confining pressure, and (ii) are suitable to extrapolate the understanding of Boom Clay rheology beyond the time scales accessible in the laboratory.

While these experimental outcomes appear promising on the first look, a more sophisticated experimental and observational setup is required to fully understand deformation of Boom Clay. Necessary modifications include for example using in-situ pore fluid compositions and measuring the incremental deformation field (Oelker et al., 2017).

\subsection{Boom Clay and Callovo-Oxfordian Clay: two end.members for the understanding of deformation in phyllosilicate-rich materials?}

At Bure (France; approx. $220 \mathrm{~km}$ ESE of Paris), the French National Radioactive Waste Management Agency (ANDRA) operates a URF to explore the feasibility of Callovo-Oxfordian 
Clay to host radioactive waste (Armand et al., 2013). There, the roughly 160 Ma old claystone is encountered in a depth between $\sim 417-547 \mathrm{~m}$ (Gaucher et al., 2004): Its mineralogical composition (26 - $42 \%$ phyllosilicates; 27 - $42 \%$ carbonates; 24 - $30 \%$ tectosilicates - mostly quartz) is comparable to the one of Boom Clay (see Table 1; Gaucher et al., 2004; Conil et al., 2018). Opposed to Boom Clay, Callovo-Oxfordian Clay is heavily cemented by secondary (i.e. diagenetic) calcite (Gaucher et al., 2004; Desbois et al., 2017a), which results in a substantially higher strength (e.g. Young's modulus: 2 - $5 \mathrm{GPa}$; unconfined compressive strength: $30 \mathrm{MPa}$; Gasc-Barbier et al., 2004; Fabre and Pellet, 2006; see also Table 2).

Deformation mechanisms in experimentally deformed Callovo-Oxfordian Clay are predominantly cataclastic with minor crystal plasticity (i.e. inter- and intragranular fragmentation; granular flow and particle rotation resulting in SPOs and particle bending; Desbois et al., 2017a). This geomecahnical behaviour contrasts strongly with the one of Boom Clay presented herein. Therefore, although at first approximation, the inelastic behaviour of cemented (e.g. Callovo-Oxfordian Clay) and uncemented (e.g. Boom Clay) phyllosilicate-rich geomaterials can be described by similar pressure-dependent hardening plasticity models, underlying microphysical mechanisms are very different indeed.

\section{Conclusions}

BIB-SEM investigations of Boom Clay experimentally deformed at confined and undrained conditions provide first detailed insights into the evolution of deformation-related microstructures, which allows in combination with data recorded during the experiments to understand the rheology of this plastic, uncemented claystone.

Deformed samples display strong strain partitioning between shear zones and the rest of the samples. Most of the strain $(\sim 80 \%)$ was accommodated outside the shear zones, mostly by pore collapse. Dominating deformation mechanisms within the shear zones are pore collapse, independent particulate flow (grain boundary sliding) and particle rotation. These mechanisms promoted particle reorientation leading to shape preferred orientations manifested by distinct foliations oblique (P-foliation) and parallel to displacement (Y-shears). Fragmentation of mica grains and intracrystalline deformation leading to bent micas are subordinate. Furthermore, succeeding initial fluid pressure increases in response to pore collapse, the formation of microcracks within shear zones resulted in decreasing pore pressures.

On macro- and mesoscale, strain localization is governed by viscosity contrast between the dominating frictionally weak phyllosilcate-rich matrix and embedded, harder quartz and feldspar grains. At these scales, shear zones localize predominantly in bands where there are less large, hard phases. At the microscale (scale of phyllosilicates constituting the matrix) strain is accommodated within shear zones by particle rotation and subsequent sliding along grain boundaries initiated by the initial phyllosilicate orientation. This "geometric softening" requires sufficiently large initial porosities.

Deformation mechanisms deduced from experimentally generated microstructures are very similar to those inferred in Boom Clay having been deformed naturally and artificially during the excavation of an Underground Research Facility at low confining pressures. Consequently, deformation experiments at low confining pressure in combination with microstructural 
analyses appear suitable to understand Boom Clay rheology on the microscale, which is required to understand its macroscale behaviour. However, further investigations will be necessary to test this hypothesis.

\section{Acknowledgements}

We thank ESV Euridice GIE for help with obtaining the core samples, Séverine Levasseur (ONDRAF-NIRAS) for manuscript's reading and Oscar Juarez (Institute of Foundation Engineering, Soil Mechanics, Rock Mechanics and Waterways Construction, RWTH Aachen University) for performing the experiments. We are very grateful to Samuel Haines and an anonymous reviewer, who helped to improve the manuscript substantially.

\section{Bibliography}

Al-Mukthar, M.A., Belanteur, N., Tessier, D., Vanapalli, S.K. (1996): The fabric of a clay soil under controlled mechanical and hydraulic stress states. Applied Clay Science 11, 99-115.

Armand, G., Noiret, A., Zghondi, J., Seyedi, D.M., 2013. Short- and long-term behaviors of drifts in the Callovo-Oxfordian claystone at the Meuse/Haute-Marne Underground Research Laboratory. Journal of Rock Mechanics and Geotechnical Engineering 5, 221 - 230, doi:10.1016/j.jmge.2013.05.005.

Baldi, G., Hueckel, T., Peano, A., Pellegrini, R., 1991a. Developments in modelling of thermohydro- geomechanical behaviour of Boom clay and clay-based buffer materials (Volume 1), Final report, Report EUR-13365/1. Luxenbourg: Commission of the European Community

Baldi, G., Hueckel, T., Peano, A., Pellegrini, R., 1991b. Developments in modelling of thermohydro-geomechanical behaviour of Boom clay and clay-based buffer materials (Volume 2), Final report, Report EUR-13365/2. Luxenbourg: Commissionof the European Comunity.

Barnichon, J.-D., Volckaert, G., 2003. Observations and predictions of hydromechanical coupling effects in the Boom clay, Mol Underground Research Laboratory, Belgium. Hydrogeology Journal 11, 193-202.

Bergerat, F., Vandycke, S., 1994. Paleostress analysis and geodynamical implications of Cretaceous-Tertiary faulting in Kent and the Boulonnais. Journal of the Geological Society, London 151, 439 - 448.

Bernier, F., Li, X.L., Bastiaens, W., Ortiz, L., Van Geet, M., Wouters, L., Frieg, B., Blümling, P., Desrues, J., Viaggiani, G., Coll, C., Chanchole, S., De Greef, V., Hamza, R., Malinsky, L., Vervoort, A., Vanbrabant, Y., Debecker, B., Verstraelen, J., Govaerts, A., Wevers, M., Labiouse, V., Escoffier, S., Mathier, J.-F., Gastaldo, L., Bühler, Ch., 2007. Fractures and Selfhealing within the Excavation Disturbed Zone in Clays (SELFRAC). Final report, European Commission, CORDIS Web Site, EUR 22585, p. 56.

Bésuelle, P., Viggiani, G., Desrues, J., Coll, C., Charrier, P., 2014. A Laboratory Experimental Study of the Hydromechanical Behavior of Boom Clay. Rock Mechanics and Rock Engineering 47, 143-155.

Blenkinsop, T., 2000. Deformation Microstructures and Mechanisms in Minerals and Rocks. Springer, p. 163. 
Boisson, J.Y., 2005. Clay Club Catalogue of Characteristics of Argillaceous Rocks, OECD/NEA/RWMC/IGSC (Working Group on measurement and Physical understanding of Groundwater flow through argillaceous media) august 2005 Report NEA no. 4436 (Brochure and CD-Rom including data base). OECD/NEA Paris, France, 72.

Borradaile, G.J., 1980. Particulate Flow of Rock and the Formation of Cleavage. Tectonophysics $72,305-321$.

Borradaile, G.J., Tarling, D.H., 1981. The Influence of Deformation Mechanisms on Magnetic Fabrics in Weakly Deformed Rocks. Tectonophysics 77, 151-168.

Cladouhos, T.T., 1999a. A kinematic model for deformation within brittle shear zones, Journal of Structural Geology 21, 437-448, doi:10.1016/S0191-8141(98)00124-2.

Cladouhos, T.T., (1999b). Shape preferred orientations of survivor grains in fault gouge. Journal of Structural Geology 21, 419 - 436, doi:10.1016/S0191-8141(98)00123-0.

Coll, C., 2005. Endommagement des roches argileuses et perméabilité induite au voisinage d'ouvrages souterrains. PhD thesis at Joseph-Fourier University- Grenoble I.

Collettini C., Niemeijer A., Viti, C., Marone C., 2009. Fault zone fabric and fault weakness. Nature 462, 907-910.

Conil, N., Talandier, J., Djizanne, H., de La Vaissière, R., Righini-Waz, C. Auvray, C., Morlot, C., Armand G., 2018. How rock samples can be representative of in situ condition: A case study of Callovo-Oxfordian claystones. Journal of Rock Mechanics and Geotechnical Engineering 10, 613-623, doi:10.1016/j.jmge.2018.02.004.

Cui, Y.-J., Le, T.T., Tang, A-M., Delage, P., Li, X.-L., 2009. Investigating the time-dependent behaviour of Boom clay under thermo-mechanical loading. Géotechnique 59 (4), 319-329.

Curtis, M.E., Sondergeld, C.H., Ambrose, R.J., Rai, C.S., 2012. Microstructural investigation of gas shales in two and three dimensions using nanometer-scale resolution imaging. AAPG Bulletin 96, 665-677.

Dehandschutter, B., Vandycke, S., Sintubin, M., Vandenberghe, N., Gaviglio, P., Sizun, J.-P., Wouters, L., 2004. Microfabric of fractured Boom Clay at depth: a case study of brittleductile transitional clay behaviour. Applied Clay Science, 26, 389-401.

Dehandschutter, B., Sintubin, S., Vandenberghe, N., Vandycke S., Gaviglio P., Wouters, L., 2002. Fracture analysis in the Boom Clay (URF, Mol, Belgium), Aarkundige Mededelingen 12, 245-248.

Dehandschutter, B., Gaviglio O., Sizun J.P., Sintubin, M., Vandycke, S., Vandenberghe, N., Wouters, L., 2005a. Volumetrix matrix strain related to intraformational faulting in argillaceous sediments. Journal of the Geological Society, London, 162, 801-813.

Dehandschutter, B., Vandycke, S., Sintubin, M., Vandenberghe, N., Wouters, L., 2005b. Brittle fractures and ductile shear bands in argillaceous sediments: inferences from Oligocene Boom Clay (Belgium). Journal of Structural Geology, 27, 1095-1112.

del Olmo, C., Fioravante, V., Gera, F., Hueckel, T., Mayor, J. C., Pellegrini, R., 1996. Thermomechanical properties of deep argillaceous formations. Engineering Geology 41, 87-101. 
Deng, Y.F., Tang, A.M., Cui, Y.J., Nguyen, X.P., Li, X.L., Wouters, L., 2011a. Laboratory Hydromechanical Characterisation of Boom Clay at Essen and Mol. Physics and Chemistry of the Earth, Parts A/B/C, Clays in Natural \& Engineered Barriers for Radioactive Waste Confinement 36, 1878-1890.

Deng, Y.F., Tang, A.M., Cui, Y.J., Li, X.L., 2011b. Study on the hydraulic conductivity of Boom clay. Canadian Geotechnical Journal 48, 1461-1470.

Den Hartog S.A.M., Spiers C., 2014. A microphysical model for fault gouge friction applied to subduction megathrusts. Journal of Geophysical Research, 119, 1510-1529.

Desbois G., Urai J.L. and Kukla P.A. (2009). Morphology of the pore space in claystones - evidence from BIB/FIB ion beam sectioning and cryo-SEM observations. E-Earth, $4: 15-22$.

Desbois G., Urai J.L., Hemes S., Brassinnes S., De Craen M., Sillen X., 2014. Nanometer-scale pore fluid distribution and drying damage in preserved clay cores from Belgian clay formations inferred by BIB-cryo-SEM. Engineering Geology 170, 117-131.

Desbois G., Höhne N., Urai J.L., Bésuelle P., Viggiano G., 2017a. Deformation in cemented mudrock (Callovo Oxfordian Clay) by micro-cracking, granular flow and phyllosilicate plasticity: insights from Triaxial Deformation, Broad ion Beam polishing and Scanning Electron Microscopy. Solid Earth 8, 291-305.

Desbois G., Schmatz J., Klaver J., Urai J.L., 2017b. Micro-fabric damages in Boom Clay inferred from cryo-BIB-SEM experiment: recent results. Geophysical Research Abstracts Vol. 19, EGU2017-4461.

Dewhurst D.N., Clennell M.B., Brown K.M, Westbrook, G.K., 1996. Fabric and hydraulic conductivity of sheared clays. Géotechnique, 46, 761-768.

Djéran-Maigre, I., Tessier, D., Grunberger, D., Velde, B., Vasseur, G., 1998. Evolution of microstructures and of macroscopic properties of some clays during experimental compaction. Marine and Petroleum Geology 15, 109-128.

Fabre, G., Pellet, F., 2006. Creep and time-dependent damage of argillaceous rocks. International Journal of Rock Mechanics \& Mining Sciences 43, 950 - 960, doi:10.1016/j.ijrmms.2006.02.004.

Fossen, H., 2016. Structural Geology. 2nd ed. Cambridge University Press, p. 510.

Gasc-Barbier, Chanchole, S., Bérest, P., 2004. Creep behavior of Bure clayey rock. Applied Clay Science 26, 449 - 458, doi:10.1016/j.clay.2003.12.030.

Gaucher, E., Robelin, C., Matray, J.M., Négrel, G., Gros, Y., Heitz, J.F., Vinsot, A., Rebours, H., Cassagnabère, A, Bouchet, A., 2004. ANDRA underground research laboratory: interpretation of the mineralogical and geochemical data acquired in the CallovianOxfordian formation by investigative drilling. Pyhsics and Chemistry of the Earth 29, 55 77, doi:10.1016/j.pce.2003.11.006.

Guo, P., Stolle, D.F.E., 2013. Coupled analysis of bifurcation and shear zone in saturated soils. Soils and foundations 53, 525-539.

Haines, S.H., Van der Pluijm, B., Ikari, M.J., Saffer, D.M., Marone, C., 2009. Clay fabric intensity in natural and artificial fault gouges: Implications for brittle fault zone processes and sedimentary basin clay fabric evolution. Journal of Geophysical Research 114, B05406. 
Haines, S.H., Kaproth, B., Marone, C., Saffer, D., Van der Pluijm, B., 2013. Shear zones in clay-rich fault gouge: A laboratory study of fabric development and evolution. Journal of Structural Geology 51, 206-225.

Handy, M.R., 1990. The Solid-State Flow of Polymineralic Rocks. Journal of Geophysical Research $95,8647-8661$.

Handy, M.R., 1994. Flow laws for rocks containing two non-linear viscous phases: a phenomenological approach. Journal of Structural Geology 16, 287 - 301.

Heath, J.E., Dewers, T.A., McPherson, B.J.O.L., Petrusak, R., Chidsey, T.C., Rinehart, A.J., Mozley, P.S., 2011. Pore networks in continental and marine mudstones: Characteristics and controls on sealing behavior. Geosphere 7, 429-454.

Hemes, S., Desbois, G., Urai, J.L., De Craen, M. and Honty, M., 2013. Variations in the morphology of porosity in the Boom Clay Formation: insights from 2D high resolution, BIB-SEM imaging and Mercury injection Porosimetry. The Netherlands Journal of Geosciences, Geologie en Mijnbouw 92, 275-300.

Hemes, S., 2015: Nm-scale pore space characteristics of the Boom Clay (Mol - 1 borehole) and the Ypresian clays (Kallo - 1 borehole). PhD thesis. RWTH Aachen University, p. 218.

Hemes, S., Desbois, G., Urai, J.L., Schröppel, B., Schwarz, J.-O., 2015. Multi-scale characterization of porosity in Boom Clay (HADES, Mol, Belgium) using a combination of $\mu$-CT, BIB-SEM and serial FIB-SEM techniques. Microporous and Mesoporous Materials 208, 1-20.

Hemes, S., Desbois, G., Urai, J.L, 2016. Microstructural characterisation of the Ypresian clays (Kallo-1) at nanometre resolution, using broad-ion beam milling and scanning electron microscopy. The Netherlands Journal of Geosciences, Geologie en Mijnbouw 95, 293-313.

Honty, M., De Craen, M., 2012. Boom Clay mineralogy - qualitative and quantitative aspects. External Report, SCK-CEN-ER-194, p. 95.

Horseman, S.T., Winter, M.G., Entwistle, D.C., 1987. Geotechnical characterization of boom clay in relation to the disposal of radioactive waste. Technical report. Commission of the European Communities, p. 100.

Horseman, S.T., Winter, M.G., Entwistle, D.C., 1993. Triaxial experiments on Boom Clay. In Cripps, J.C., Coulthard, J.M., Culshaw, M.G., Forster, A., Hencher, S.R., Moon, C.F. (Eds.). The Engineering Geology of Weak Rock, 35-43.

Houben, M.A., Desbois, G., Urai, J.L., 2013. Pore morphology and distribution in the shaly facies of Opalinus clay (Mont Terri, Switzerland): insights from representative 2D BIB-SEM investigations on mm- to nm- scales. Applied Clay Sciences 71, 82-97.

Houben, M.A., Desbois, G., Urai, J.L., 2014. A comparative study of representative 2D microstructures in Shaly and Sandy facies of Opalinus Clay (Mont Terri, Switzerland) inferred form BIB-SEM and MIP methods. Marine and Petroleum Geology 49, 143-161.

Ikari, M.J., Niemeijer, A.R., Marone, C., 2015. Experimental investigation of incipient shear failure in foliated rock. Journal of Structural Geology 77, 82-91.

Ingram, G.M., Urai, J.L., 1999. Top-seal leakage through faults and fractures: the role of mudrock properties. Geological Society, London, Special Publications 158, 125-135. 
Jessell, M.W., Bons, P.D., Griera, A., Evans, L., Wilson, C.J.L., 2009. A tale of two viscosities. Journal of Structural Geology 31: 719-736

Kanit, T., Forest, S., Galliet, I., Mounoury, V., Jeulin, D., 2003. Determination of the size of the representative volume element for random composites: statistical and numerical approach. International Journal of Solids and Structures 40, 3647-3679.

Kaufhold, A., Halisch, M., Zacher, G., Kaufhold, S., 2016. X-ray computed tomography investigation of structures in Opalinus Clay from large-scale to small-scale after mechanical testing. Solid Earth 7, 1171-1183.

Keller, L.M., 2015. On the representative elementary volumes of clay rocks at the mesoscale. Journal of Geology and Mining Research 7, 58-64.

Kenney, T.C., 1977. Residual strengths of mineral mixtures. Proceedings of the 9th International Conference on Soil Mechanics and Foundation Engineering 1, 155-160.

Klaver, J., Desbois, G., Urai, J.L., Littke, R., 2012. BIB-SEM study of porosity of immature Posidonia shale from the Hils area, Germany. International Journal of Coal Geology 103, 12-25.

Klaver, J., Desbois, G., Littke, R., Urai, J.L., 2015. BIB-SEM characterization of pore space morphology and distribution in postmature to overmature samples from the Haynesville and Bossier Shales, Marine and Petroleum Geology 59, 451-466.

Klinkenberg, M., Kaufhold, S., Dohrmann, R., Siegesmund, S., 2009. Influence of carbonate microfabrics on the failure strength of claystones. Engineering Geology 107, 42-54.

Kraus, W., 2002. ATP Reagenz und Lamipeel. Der Präparator, 48, 51-75.

Labiouse, V., Sauthier, C., You, S., 2013. Hollow Cylinder Simulation Experiments of Galleries in Boom Clay Formation. Rock Mechanics and Rock Engineering 47, 43-55.

Laenen, B., 1997. The geochemical signature of relative sea-level cycles recognized in the Boom Clay. PhD thesis. Katholieke Universiteit Leuven, p. 396.

Laurich, B., Urai, J.L., Desbois, G., Vollmer, C., Nussbaum, C., 2014. Microstructural evolution of an incipient fault zone in Opalinus Clay: Insights from an optical and electron microscopic study of ion-beam polished samples from the Main Fault in the Mont Terri underground research laboratory. Journal of Structural Geology 67, 107-128.

Laurich, B., Urai, J.L., Nussbaum, C., 2017a. Microstructures and deformation mechanisms in Opalinus Clay: insights from scaly clay from the Main Fault in the Mont Terri Rock Laboratory (CH). Solid Earth 8, 27-44.

Laurich, B., Urai, J.L., Vollmer, C., Nussbaum, C., 2018. Deformation mechanisms and evolution of the microstructure of gouge in the Main Fault in Opalinus Clay in the Mont Terri rock laboratory (CH). Solid Earth 9, 1-24, doi:10.5194/se-9-1-2018.

Lee, M.R., Bland, P.A., Graham, G., 2003. Preparation of TEM samples by focused ion beam (FIB) techniques: applications to the study of clays and phyllosilicates in meteorites. Mineralogical Magazine 67, 581-592.

Logan J.M., Friedman M., Higgs N., Dengo C., Shimamoto T. (1979). Experimental studies of simulated gouge and their application to studies of natural fault zones, in: Proceedings of Conference VIII on Analysis of Actual Fault Zones in Bedrock. US Geological Survey, Open File Report, pp. 79-1239. 
Logan J.M., Rauenzahn K.A. (1987). Frictional dependence of gouge mixtures of quartz and montmorillonite on velocity, composition and fabric. Tectonophysics, 144: 87-108.

Logan J.M., Dengo C.A., Higgs N.G., Wang Z.Z. (1992). Fabrics of Experimental Fault Zones: Their Development and Relationship to Mechanical Behavior, in: Evans, B., Wong, T. (Eds.), Fault Mechanics and Transport Properties of Rocks- A Festschrift in Honor of W. F. Brace. Academic Press, pp. 33-67.

Lupini, J.F., Skinner, A.E., Vaughan, P.R., 1981. The drained residual strength of cohesive soils. Géotechnique 31,181-213.

Marone, C., Scholz, C.H., 1989. Particle-size distribution and microstructures within simulated fault gouge. Journal of Structural Geology, 11, 799-814.

Mendoza, R.C., 2004). Determination of Lateral Stresses in Boom Clay using Lateral Stress Oedometer. MA thesis. Enschede, the Netherlands: International Institute for GeoInformation Science and Earth Observation.

Mertens, J., Vandenberghe, N., Wouters, L., Sintubin, M., 2003. The origin and development of joints in the Boom Clay Formation (Rupelian) in Belgium. In van Rensbergen, P., Hillis, R.R., Maltman, A.J., Morley, C.K. (Eds.). Subsurface Sediment Mobilization. Geological Society, London, Special Publications 216, 309-321.

Mertens, J., Bastiaens, W., Dehandschutter, B., 2004. Characterisation of induced discontinuities in the Boom Clay around the underground excavations (URF, Mol, Belgium). Applied Clay Science 26, 413 - 428, doi:10.1016/j.clay.2003.12.017

Milliken, K.L., Reed, R.M., 2010. Multiple causes of diagenetic fabric anisotropy in weakly con-solidated mud, Nankai accretionary prism, IODP Expedition 316. Journal of Structural Geology 32, 1887- 1898.

Monfared, M., Sulem, J., Delage, P., Mohajerani, M., 2012. On the THM behaviour of a sheared Boom clay sample: Application to the behaviour and sealing properties of the EDZ. Engineering Geology 124, 47-58.

Moore, D.E., Lockner, D.A., 2004. Crystallographic controls on the frictional behavior of dry and water-saturated sheet structure minerals. Journal of Geophysical Research 109, doi:10.10292003JB002582.

Moore, D.E., Lockner, D.A., 2007. Friction of the Smectite Clay Montmorillonite. In Dixon, T., Moore, C. (Eds.). The Seismogenic Zone of Subduction Thrust Faults, 317 - 345.

Morgenstern, N.R., Tchalenko, J.S., 1967. Microscopic structures in kaolin subjected to direct shear. Géotechnique, 17, 309-328.

Morrow, C.A., Moore, D.E., Lockner, D.A., 2017. Frictional strength of wet and dry montmorillonite. Journal of Geophysical Research: Solid Earth 122, 3392 - 3409, doi:10.1002/2016JB013658.

Nardini, L., Rybacki, E., Döhmann, M.J.E.A., Morales, L.F.G. Brune, S., Dresen, G., 2018. Hightemperature shear zone formation in Carrara marble: The effect of loading conditions. Tectonophysics 749, 120-139. 
Niemeijer, A., Spiers, C., 2007. A microphysical model for strong velocity weakening in phyllosilicate-bearing fault gouges. J. Geophys. Res. B 112. http://dx.doi.org/ 10.1029/2007JB005008.

Oelker A., Desbois, G., Urai, J.L., Bésuelle, P., Viggiani, G., Levasseur, S., 2017. Macroscale deformation behavior and characterization of deformation mechanisms below $\mu \mathrm{m}$-scale in experimentally deformed Boom Clay by using the combination of triaxial compression, Xray $\mu$-CT imaging, DIC, BIB cross-sectioning, and SEM. Geophysical Research Abstracts,Vol. 19, EGU2017-13261-1.

ONDRAF/NIRAS, 2001. SAFIR 2, Safety Assessment and Feasibility Interim Report 2, NIROND 2001-06.

Passchier, C. W., Trouw, R. A. J., 2005. Microtectonics. 2nd ed. Springer, p. 371.

Petley, D.N., 1999. Failure envelopes of mudrocks at high confining pressures. In: Aplin, A.C., Fleet, A.J., Macquaker, J.H.S. (Eds.). Muds and Mudstones: Physical and Fluid Flow Properties. Geological Society, London, Special Publications 158, 61 - 71.

Philipp, T., Amann-Hildenbrand, A., Laurich, B., Littke, R., Urai, J.L., Desbois, G., 2017. The effect of microstructural heterogeneity on pore size distribution and permeability in Opalinus Clay (Mont Terri, $\mathrm{CH}$ ): insights from an integrated study of laboratory fluid flow and pore morphology from BIB-SEM images. In Rutter, E.H., Mecklenburgh, J., Taylor, K.G. (Eds.). Geomechanical and Petrophysical Properties of Mudrocks. Geological Society, London, Special Publications 454, doi:10.1144/SP454.3.

Piriyakul, K., 2006. Anisotropic Stress-Strain Behaviour of Belgian Boom Clay in the Small Strain Region. PhD thesis. Gent, Belgium: Universiteit Gent.

Porter, J.R., Knipe, R.J., Fischer, Q.J., Farmer, A.B., Allin, N.S., Jones, L.S., Palfrey, A.J., Garrett, S.W., Lewis, G., 2000. Deformation processes in the Britannia Field, UKCS. Petroleum Geosciences 6, 241 - 254.

Ritsema, C.J., Groenenberg, J.E., 1993. Pyrite Oxidation, Carbonate Weathering, and Gypsum Formation in a Drained Potential Acid Sulfate Soil. Soil Science Society of America Journal $57,968-976$.

Roscoe, K.H., Schofield, A.N., Wroth, C.P., 1958. On the yielding of soils. - Géotechnique 8, 22 - 53.

Roscoe, K.H., Burland, J.B., 1968. On the generalised stress-strain behaviour of "wet" clay. In: Heyman, J., Leckie, C.F. (Eds.). Engineering Plasticity, 535 - 609.

Rutter, E.H., Maddock, R.H., Hall, S.H., White, S.H., 1986. Comparative microstructures of natural and experimentally produced clay-bearing fault gouges. Pure and Applied Geophysics, 124, 3-30.

Rybacki, E., Morales, L.F.G., Naumann, M., Dresen, G., 2014. Strain localization during high temperature creep of marble: The effect of inclusions. Tectonophysics 634, 182-197.

Saffer, D., Marone, C., 2003. Comparison of smectite- and illite-rich gouge frictional properties: Application to the updip limit of the seismogenic zone along subduction megathrusts, Earth and Planetary Science Letters 215, 219-235, doi:10.1016/S0012-821X(03)00424-2.

Schindelin, J., Arganda-Carreras, I., Frise, E., Kaynig, V., Longair, M., Pietzsch, T., Preibisch, S., Rueden, C., Saalfeld, S., Schmid, B., Tinevez, J.-Y., White, D.J., Hartenstein, V., Eliceiri, K., 
Tomancak, P., Cardona, A., 2012. Fiji: an open-source platform for biological-image analysis. Nature methods 9, 676-682.

Schittekat, J., Henriet, J.P., Vandenberghe, N., 1983. Geology and geotechnique of the Scheldt Surge Barrier. Characteristics of an overconsolidated clay. 8th International Harbour Congress 2, 121-135.

Schleicher A.M., van der Pluijm, B.A., Warr, L.N., 2010. Nanocoatings of clay and creep of the San Andreas Fault at Parkfield, California. Geology 38, 667 - 670, doi: 10.1130/G31091.1.

Schofield, A. N. \& Wroth, C. P. (1968): Critical state soil mechanics. McGraw-Hill, p. 310.

Schuck, B., Janssen, C., Schleicher, A.M., Toy, V.G., Dresen, G., 2018. Microstructures imply cataclasis and authigenic mineral formation control geomechanical properties of New Zealand's Alpine Fault. Journal of Structural Geology 110, 182-186.

Shen, H., Lissenden, C.J., 2005. Stress and Strain Localization Three Dimensional Modelling for Particle-Reinforced Metal Matrix Composites. Metallurgical and materials transactions 36a, 1653-1660.

Sultan, N., Cui, Y.J., Delage, P., 2010. Yielding and plastic behaviour of Boom Clay. Géotechnique 60, 657-666.

Taylor, R.N., Coop, M.R., 1993. Stress path testing of Boom Clay from Mol, Belgium. In Cripps, J.C., Coulthard, J.M., Culshaw, M.G., Forster, A., Hencher, S.R., Moon, C.F. (Eeds.). The Engineering Geology of Weak Rock, 77-82.

Tembe, S., Lockner, D.A., Wong, T.-F., 2010. Effect of clay content and mineralogy on frictional sliding behavior of simulated gouges: Binary and ternary mixtures of quartz, illite, and montmorrilonite. Journal of Geophysical Research 115, doi:10.1029/2009JB006383.

Vandenberghe, N., de Craen, M., Wouters, L., 2014. The Boom Clay Geology. From sedimentation to present-day occurence. A review. Memoirs of the Geological Survey of Belgium 60, p. 76.

Vandycke, S., 2002. Paleostress records in Cretaceous formations in NW Europe: extensional and strike-slip events in relationships with Cretaceous-Tertiary inversion tectonics.

Vasseur, G., Djéran-Maigre, I., Grunberger, D., Rousset, G., Tessier, D., Velde, B., 1995. Evolution of structural and physical parameters of clays during experimental compaction. Marine and Petroleum Geology 12, 941-954.

Viggiani, G., Hall, S.A., 2008. Full-field measurements, a new tool for laboratory experimental geomechanics. In Burns, S.E., Mayne, P.W., Santamarina, J.C. (Eds.). Proc. 4th Int. Symp. Deformation Characteristics Geomater. IOS Press 1, 3-26.

Yu, H.-D., Chen, W.-Z., Jia, S.-P., Cao, J.-J., Li, X.-L., 2012. Experimental study on the hydromechanical behavior of Boom clay. International Journal of Rock Mechanics and Mining Sciences 53, 159-165.

Warr, L.N., Wojatschke, J., Carpenter, B.M., Marone, C., Schleicher, A.M., van der Pluijm B.A., 2014. A "slice-and-view" (FIB-SEM) study of clay gouge from the SAFOD creeping section of the San Andreas Fault at 2.7 km depth. Journal of Structural Geology 69, 234-244.

Wojatschke, J., Scuderi, M.M., Warr, L.N., Carpenter, B.M., Saffer, D., Marone, C., 2016. Experimental constraints on the relationship between clay abundance, clay fabric, and 
frictional behaviour for the Central Deforming Zone of the San Andreas Fault. Geochemistry, Geophysics, Geosystems 17, 3865 - 3881, doi:10.1002/2016GC006500.

Wood, D.M., 1990. Soil Behaviour and Critical State Soil Mechanics. Cambridge University Press, p. 480.

Wu, F.T. (1978). Mineralogy and physical nature of clay gouge. Pure and Applied Geophysics, $116,655-689$.

Zeelmaeker, E. Honty, M., Derkowski, A., Rodon, J.S., De Craen, M., Vandenberghe, N., Adriaens, R., Ufer, K., Vouters, L., 2015. Qualitative and quantitative mineralogical composition of the Rupelian Boom Clay in Belgium. Clay Minerals 50, 249-272. 


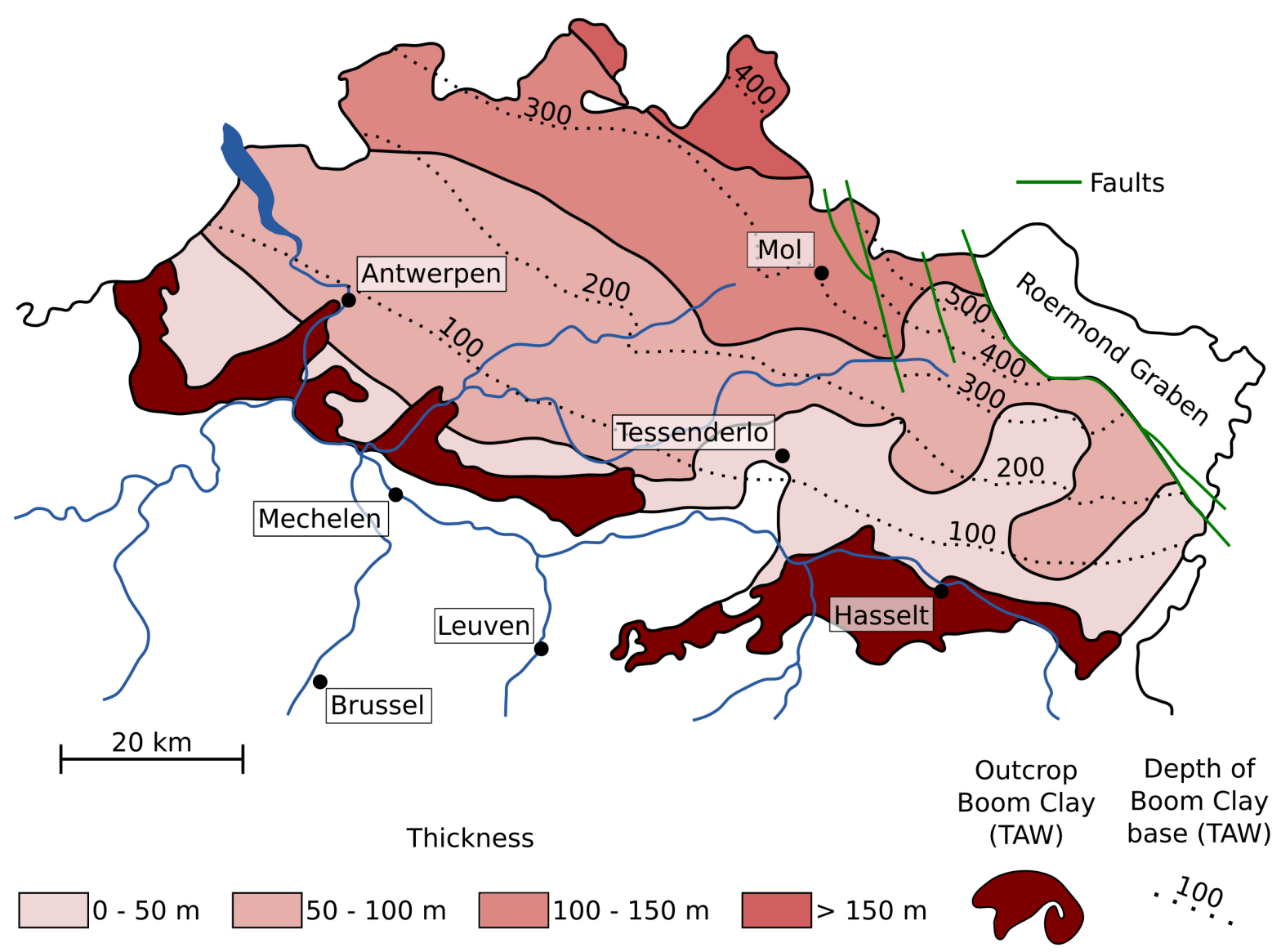

Figure S1. Boom Clay Formation: outcrop area, thickness and depth of the formation base in Belgium. Depth is given in TAW ('tweede algemeene waterpassing'): the topographic reference zero level in Belgium, $2.33 \mathrm{~m}$ below the sea level (Hemes 2015). Figure after ONDRAF/NIRAS 2001. 